\title{
ANTI-LIBERAL, ANTI-ESTABLISHMENT OR CONSTITUENCY-DRIVEN? SPATIAL ECONOMETRIC ANALYSIS OF POLISH PARLIAMENTARY ELECTION RESULTS IN 2015
}

\begin{abstract}
We investigated the spatial variation patterns of voting results in Polish parliamentary election in 2015 across 380 regions. That election was a milestone event in Polish politics that substantially affected Poland's internal and foreign policy directions and promoted two emerging political parties as runners-up against the well-established ones. While socio-economic, cultural and geographical factors such as economic activity, historical legacies (post-Russian East vs post-German West) and economic dichotomies (cities vs the countryside) explain most variations for most parties, they do not appeared to fit as determinants of the new parties' support, especially of right-wing populists. Demographic target groups of individual parties appear to be relatively unresponsive to their pre-election offerings. The spatial specification of econometric models considerably improves their statistical properties. We also examined mixed-W models to account for the unobservable spatial effects stemming from the construction of constituencies. Their distinctive sets of candidates added significantly to the explanation of the spatial variation in voting.
\end{abstract}

Key words: spatial analysis, election results, Poland, constituencies, mixed-W models.

\section{INTRODUCTION}

On 25th October 2015 the Polish parliamentary elections were held, resulting in the victory of a right-wing, nationally and socially conservative party Law and Justice (Prawo i Sprawiedliwość, $\mathrm{PiS}^{1}$, member of the European Parliament's

\footnotetext{
*Aleksandra LASOŃ, University of Amsterdam; e-mail: lason.aleksandraa@gmail.com.

** Andrzej TORÓJ, SGH Warsaw School of Economics, Institute of Econometrics, ul. Madalińskiego 6/8, 02-513 Warsaw, Poland; e-mail: andrzej.toroj@sgh.waw.pl;

ORCID http://orcid.org/0000-0003-3623-168X.

1 Abbreviations: PiS - Law and Justice (Prawo i Sprawiedliwość), PO - Civic Platform (Platforma Obywatelska), K15 - Kukiz'15, N - Modern (.Nowoczesna), PSL - Polish People's Party (Polskie
} 
group European Conservatives and Reformists). The liberal Civic Platform (Platforma Obywatelska, PO, member of the Christian democratic European People's Party group at the European Parliament) and the agrarian Polish People's Party ${ }^{2}$ (Polskie Stronnictwo Ludowe, PSL, another EPP member), which had governed since 2007, stepped back to the opposition. At the same time, two brand-new groups entered the parliament, the right-wing populist Kukiz'15 (K15, never before in the EP) and the liberal Modern (.Nowoczesna, N, formal member of the Alliance of Liberals and Democrats for Europe). ${ }^{3}$ Law and Justice became the first party in Poland since pre-1989 communist era to secure an absolute majority of seats in the Sejm, the lower house of the Parliament, which enabled them to appoint an autonomous government.

The changes on the Polish political scene coincided with the rise of populist, anti-immigration and anti-establishment sentiments and parties in Europe (cf. Algan et al., 2017), such as Alternative für Deutschland in Germany, Freiheitliche Partei Österreichs in Austria, Swedish democrats - Sverigedemokraterna or Danish People Party - Dansk Folkeparti. They also shortly preceded the anti-establishment campaigns in the UK and the US that paved the way towards the vote for Brexit and the victory of Donald Trump, respectively, as well as the historically best results of the French Front National in 2017. A question that arises is to what extent the Polish election results from 2015 fit this broad international context, as the voters were able to not only choose between the right-wing opposition (PiS) and the liberal, long-standing incumbent party (PO), but also the well-established parties (PiS, PO) and absolute newcomers $(\mathrm{K} 15, \mathrm{~N})$ that, in the Polish system, are by law financially handicapped on their way to the Parliament through the lack of financing from public sources and hence, to be successful, have to target emerging anti-establishment sentiments very skilfully.

A more specific question that we intend to address in this article is related to the spatial distribution of such sentiments (see, e.g. van Gent et al., 2013). We examined at the level of poviats (380 units in Poland) to find a relationship between the voting behaviour and a wide range of variables defining the regional socio-economic context, putting the problem into the spatial political economy perspective (cf. Morton, 2017). This approach might be interesting for at least three reasons.

Firstly, to the best of our knowledge, no studies have attempted to discuss the results of Polish elections in 2015 from a multivariate spatial analysis. Żerkowska-

Stronnictwo Ludowe), EU - European Union, EP - European Parliament, EPP - European People's Party, PKW - National Electoral Commission (Państwowa Komisja Wyborcza), BMA - Bayesian Model Averaging.

${ }^{2}$ PSL is the only political group represented in the parliament after 2015 election that is not analysed here due to a relatively low support, concentrated in the rural areas.

${ }_{3}$ Tags and descriptions of individual parties based on their individual websites, as well as on http:// www.parties-and-elections.eu/poland.html. 
Balas, Lyubashenko and Kwiatkowska (2016) analysed how the social statuses of individuals, ideological and cultural issues, as well as economic factors, determine electoral decisions, stating that variables describing citizens' social statuses explain in the most appropriate way the tendency to vote for individual parties. Turska-Kawa (2016) evaluated the system of higher-order values of the 2015 electorates and individuals with different ideological self-identifications. All these micro-studies might be treated as a suggestion to use respective, feasible socio-economic regressors at the local level.

Secondly, regional studies are the key to a correct understanding of the nexus between constituency formation and election outcomes. Conclusions could be relevant for a wide range of countries (though we leave them outside the scope of this paper).

Thirdly, in recent years, there has been an increase in interest in the role of party leaders in elections and the personalisation of politics (Barisione (2009), Bittner (2018), Garzia (2011), Garzia (2012), Mughan (2015), Rahat and Sheafer (2007)). Peszyński (2016) examined the leader effect on the 2015 Polish election results of their party or group, refuting the hypothesis that a party leader is a more important determinant of electoral decisions in the case of new, leader-driven parties ( $\mathrm{N}$ and K15) than in the case of more institutionalised entities (PiS and PO). Corresponding with the current research trend, spatial studies allow to capture the non-observable effect of the local leaders' charisma on the voting result, at least when the election is held in constituencies, and are perhaps the only non-survey (and hence non-declarative) method of looking into this phenomenon.

In our study, we conducted a spatial econometric investigation of the drivers that impacted the following variables: (i) the unprecedented support for PiS, (ii) the support for other parties, (iii) the vote split between right-wing and liberal-wing, as well as old $v s$ new parties, and (iv) the voter turnout. Our research hypotheses included (H1) the dominant role of socio-economic factors, which can be linked with parties' specific policy promises and target electorate, in determining regional aggregate choices (see Sections 2 and 3 for details), (H2) the presence of spatial patterns due to both spillovers of various kinds and the unobservable effects related to the candidates' attractiveness in individual constituencies, and (H3) different decision-making mechanisms with respect to the choice between liberal and conservative, and between well-established and new parties.

The data used in the paper, available via Local Data Bank from Statistics Poland, as well as the data from the National Electoral Commission (Państwowa Komisja Wyborcza, PKW), included poviat-level data (380 units in Poland at the EU's NUTS-4 level). Taking into consideration the fact that the poviat-level offers a broader set of determinants than the gmina-level data (2479 the EU's NUTS-5 units), NUTS-4 was chosen as representing an optimum balance between spatial 
precision (multiple poviats per constituency, in almost all cases) and the availability of potential regressors. After the preliminary extraction of 363 socio-economic variables available from Statistics Poland's Local Databank, due to the constrained number of territorial units and on the literature basis, we chose or constructed 54 that could most likely determine election behaviours. ${ }^{4}$ We used the General-to-Specific modelling approach, as well as the Bayesian Model Averaging (BMA) technique, as methods for handling model uncertainty. In the final stage, we applied spatial econometric models to consider the presence of additional spatial processes.

The remainder of the paper is organised as follows. In Section 2, we reviewed the previous literature related to spatial methods and their use in political science, as well as the existing literature on turnout and political preferences. In Section 3, we presented the process of data selection and the preliminary linear regression. In Section 4, we applied spatial econometric analysis and we discussed the results of this application. Section 5 is the final concluding section.

\section{ELECTORAL GEOGRAPHY IN POLAND: BACKGROUND INFORMATION AND LITERATURE REVIEW}

In an announcement of 27 October 2015, the National Electoral Commission in Poland stated that PiS received $37.58 \%$ of votes, which translated into 235 out of 460 parliamentary seats (see Table 1). PO gained 24.09\% votes (138 seats), recording a decrease of 15 percentage points compared to the election results in 2011. PiS and PO have been the leading parties on the Polish political scene since the parliamentary election in 2005.

Looking at the spatial distribution of election results, PiS was more popular among voters in eastern and south-eastern regions, while PO recorded the highest scores in the north-west, the west and the south-west, as well as had a clearly more metropolitan electorate than PiS (see Fig. 1). Relatively high support for $\mathrm{N}$ could be seen in cities with poviat rights and in the south-western part of the country. The high support for $\mathrm{N}$ in south-western Poland coincided with a high support for the Civic Platform in that part of Poland. This may suggest that the electorate of both parties had a similar profile, as well as that $\mathrm{N}$ as a newcomer seized some of PO's voters. However, no material spatial patterns emerged in the case of K15.

\footnotetext{
${ }^{4}$ The variables rejected at this stage comprised mostly highly disaggregated local government expenditure values and detailed, bookkeeping-related breakdowns related to the European Union funds absorption.
} 
Table 1. Poland's parliamentary election in 2015: country and poviat-level results [\%]

\begin{tabular}{|c|c|c|c|c|c|}
\hline & $\begin{array}{c}\text { National } \\
\text { result }\end{array}$ & $\begin{array}{c}\text { Poviat-level } \\
\text { unweighted } \\
\text { mean }\end{array}$ & $\begin{array}{c}\text { Poviat-level unweighted } \\
\text { standard error }\end{array}$ & $\begin{array}{c}\text { Poviat-level } \\
\text { maximum } \\
\text { value }\end{array}$ & $\begin{array}{c}\text { Poviat-level } \\
\text { minimum } \\
\text { value }\end{array}$ \\
\hline PiS & 37.58 & 39.13 & 10.59 & 69.87 & 17.76 \\
\hline K15 & 8.81 & 9.13 & 1.75 & 22.18 & 5.02 \\
\hline PO & 24.09 & 22.22 & 7.96 & 41.35 & 5.68 \\
\hline N & 7.60 & 6.01 & 2.58 & 16.49 & 1.31 \\
\hline
\end{tabular}

Source: own work, PKW (National Electoral Commission in Poland).

In recent years, research about the determinants of electoral behaviours, focusing on voter turnout, has expanded rapidly. Around 200 studies on turnout were published only in 2014, which is nearly four times the number of articles published in 2000 (Cancela and Geys, 2016). The meta-analysis of 83 aggregate-level studies (Geys, 2006) and its extension (Cancela and Geys, 2015) indicated that voter turnout studies conducted as multivariate regression analyses included at least one of 14 variables:

- socio-economic: population size, population concentration (though weakly correlated with voter turnout), population stability (measured by three factors: population mobility, population growth and the percentage of homeowners in the community), income homogeneity and ethnical homogeneity, proportion of minorities (turnout is lower if the share of a minority in the population is higher), past turnout;

- political: closeness of election (Fauvelle-Aymar and François, 2006) - there is a positive relation between the competitiveness of an election and the percentage of voters come to vote, political fragmentation (Dettrey and Schwindt-Bayer, 2009), campaign expenditures (Hogan, 2013; Holbrook and Weinschenk, 2014);

- institutional: electoral system (Eggers, 2015; Endersby and Krieckhaus, 2008), compulsory voting (Fowler, 2013), registration requirements (Ansolabehere and Konisky, 2006), and concurrent elections (Nikolenyi, 2010).

While looking for spatial determinants of the voting behaviour, some further country-specific aspects should be borne in mind, both in the long-term perspective and related to the specific electoral circumstances in 2015 . From this point on, we limited their presentation to the factors that were potentially relevant in the spatial dimension.

Following the first elections in Poland after the systemic transformation out of communism initiated in 1989, one could observe significant regional differences in both election results and turnout. Polish electoral geography literature indicates two main aspects of spatial differentiation of electoral behaviours. According to 
the first one, the main reason for electoral disproportionality are historical and cultural circumstances, while the second one focuses on socio-economic factors (Zarycki, 1997). The first theory emphasizes the relevance of the partitions of Poland (that took place towards the end of the $18^{\text {th }}$ century and resulted in the elimination of Poland's sovereignty for 123 years) and the resulting historically shaped political attitudes. For a long time, the highest turnouts were recorded in the north-western, western and southern regions. This regularity is often explained by long-term parliament traditions that characterize societies living in Prussian and Austrian states, while eastern communities developing within the Russian Empire, due to the authoritarian regime, did not have the appropriate conditions to progress (Kowalski, 2003). Life in a given partition led to the formation of distinct social norms and political views (Krzemiński, 2009). The second concept rejects historical influence, explaining election behaviours predominantly using contemporary socio-economic situations. Our analysis builds predominantly upon the second approach.
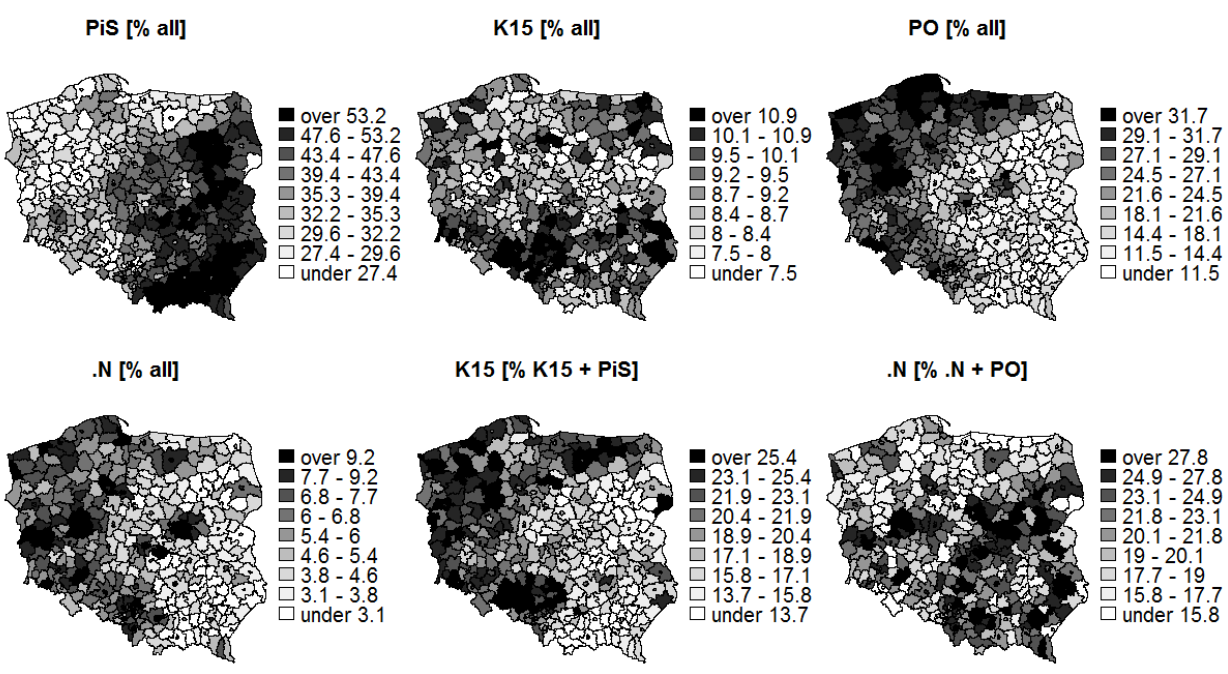

Pis + K15 [\% 4 parties $]$

$. \mathrm{N}+\mathrm{K} 15[\% 4$ parties $]$

Participation [\%]
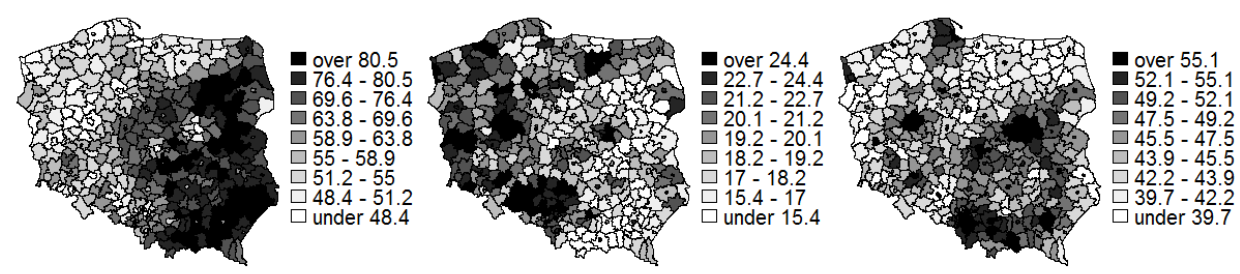

Fig. 1. Spatial distribution of dependent variables

Source: own work, National Electoral Commission (pkw.gov.pl). 
Additionally, Poland has considerably benefited from the accession to the European Union in 2004 by receiving a substantial inflow of EU funds. In the 2007-2013 financial perspective, Poland has been the largest beneficiary of the EU policy of economic and social cohesion, having the amount of 67.3 billion euros at its disposal, over 19\% of funds allocated by the EU for the purposes of this policy (see Ministry of Regional Development, Poland National Strategic Reference Framework 2007-2013). The 'Operational Programme Development of Eastern Poland', focused on, e.g. generating a socio-economic upgrade of five eastern voivodships (lubelskie, podkarpackie, podlaskie, świętokrzyskie and warmińsko-mazurskie), ${ }^{5}$ the least-developed regions in the entire EU as of 2004. The considerable investments undertaken, mainly in infrastructure, may have affected the traditional Polish electoral geography of rightwing dominance in the east.

In the years preceding 2015 election, in the majority of Polish cities with populations above 100,000 , one could observe a population decline, mainly driven by great number of city dwellers moving to the neighboring small towns and rural areas (Biegańska and Szymańska, 2013), which possibly implied some spatial autoregression pattern driven by an increasing population of commuters.

As for the electoral campaign itself, PiS made a number of attractive promises, most notably (i) reversing the incumbent PO's reform of increasing the retirement age, which had been supposed to stabilise the public finances in the long term (see Jabłonowski, Müller, 2013), and (ii) introducing additional child benefits. ${ }^{6}$ Both of those key offerings may have induced a link between the election outcomes and regional demographic conditions.

The parliamentary election in October 2015 was directly preceded by a presidential run-up in May (also won by PiS). The presidential election gave a considerable boost to the political career of Pawel Kukiz, a former rock star, and his newly created group K15 was considered in the media as a potential coalition member in the absence of the parliamentary majority for PiS. Its main aim was to create a new constitution and lead to a deep transformation of the political system in Poland, with emphasis put on single-candidate elections as a means of weakening the political parties. ${ }^{7}$ While, formally, K15 was not established as a political party, a large number of candidates were members of smaller right-wing parties, not least extreme right. The micro-level study of Turska-Kawa (2016) showed that the voters of K15 represented the most contrasting system of values against other parties.

\footnotetext{
5 http://ec.europa.eu/regional_policy/en/atlas/programmes/2007-2013/poland/operational-programme-development-of-eastern-poland [accessed 30.07.2018]

${ }^{6} \mathrm{http}: / /$ wybierzpis.org.pl/materialy-programowe [accessed 30.07.2018]

${ }^{7} \mathrm{http}: / /$ ruchkukiza.pl/klub-poselski/strategia-zmiany/ [accessed 30.07.2018]
} 
The main purpose of PO's campaign ${ }^{8}$, in turn, was to retain voters after the long period of governance since 2007 that covered different phases of the financial and economic crisis, predominantly in the euro zone. The party faced an additional, unexpected threat of voter loss due to the establishment of a new liberal and pro-EU party N. This group largely targeted its programme at young voters with higher education, and entrepreneurs interested in liberal economic policy $^{9}$, which once had been identified with PO. N's premise was to simplify the tax system, remove union and pension privileges, as well as to improve the education system to suit the labour market. It also promoted the state's ideological neutrality. The political offering of $\mathrm{N}$ appeared to be addressed predominantly to big city residents, and the spatial effects of this targeting strategy may had followed.

According to Wcisel (2016), the issue of the migrant crisis that emerged during the parliamentary campaign suggested that a large part of the electorate wanted to protect Poland against the influx of refugees and promote nationalistic attitudes. In 2015, during the peak of the European refugee crisis, PiS opposed the reception of any immigrants. However, Poland is highly homogeneous in terms of resident nationality, and - on top of that - no material spatial pattern of minority distribution emerges, so it would be unjustified to expect any spatial pattern in the anti-immigrant sentiment. That focus of the campaign, however, might had been the reason for including some symptomatic variables that might had been related to cultural or historical backgrounds of individual regions.

Finally, as our research applied to the subnational level, we omitted institutional and political variables focusing on socio-economics ones. Common institutional determinants applied to all regions: voting is voluntary, previous registration is not required, voters who are away from their place of residence on the day of an election may vote at any polling station. 460 members of the lower house of the Parliament are elected through proportional representation in 41 constituencies. Constituencies consist of groups of poviats covering parts of voivodships, or entire, smaller voivodships (NUTS-2 level). It implies that there are spatial clusters of poviats with the same sets of candidates. Each constituency has a number of mandates calculated0on the basis of its population (from 7 in a constituency with the lowest number of inhabitants to 20 mandates in the capital city Warsaw). Furthermore, as opposed to federal states or econometric time series setup, political determinants such as political fragmentation and campaign expenditures are not applicable in Poland, either. The political fragmentation is perceived unitarily, as opinion polls are conducted on the na-

\footnotetext{
${ }^{8}$ http://www.platforma.org/aktualnosc/42974/program [accessed 30.07.2018]

${ }^{9}$ https://nowoczesna.org/program-nowoczesnej-w-pigulce/ [accessed 30.07.2018]
} 
tional level. What is more, campaign expenditures are difficult to regionalise in practice, especially when political campaigns have largely shifted to the Internet in the recent years.

Since political science data is frequently spatial (Darmofal, 2006), spatial statistics and econometrics are relatively widely used in political research worldwide, especially the United States (due to the Electoral College and the "winner-takes-it-all" system), and our analysis was also related to this strand of literature.

Answering to the questions about the extent to which the U.S. is segregated by the political preferences, Cho, Gimpel and Hui (2012) relied on data for migrants across seven states to show that many Republicans and Democrats relocate on the basis of destination characteristics, such as income, racial composition and population density, but they also prefer to relocate into areas populated by copartisans. The research confirmed the previous study of Seabrook (2009) which investigated the patterns of geographical clustering in the U.S. votings for the presidential elections of 2004 and 2008. Seabrook pointed out that the change in the presidential voting appeared to be significantly more spatially dependent than the raw voting itself, suggesting a high degree of geographical clustering. Then again, Chen and Rodden (2013) demonstrated that partisan bias in U.S. legislative elections can emerge from patterns of human geography, where Democrats are inefficiently concentrated in large cities and can expect to win less than $50 \%$ of the seats when they win $50 \%$ of the votes.

In Europe, the geographical variability of electoral turnout determinants was examined by Mansley and Demsar (2015). The example of the London mayoral election in 2012 showed that electoral behaviours vary over geographical space and that some variables that are considered to influence the turnout in a specific way act non-uniformly across space and sometimes even change the direction to the opposite of the traditionally assumed effect. Regarding France, Saib (2017) tried to identify the share of inequalities in voter turnout that directly results from the specific socio-economic factors of the studied areas, in order to distinguish specific neighbourhood effect.

\section{EMPIRICAL STRATEGY}

In order to conduct a spatial econometric investigation of the drivers that impacted on the turnout level, the support for particular parties, especially the unprecedented support for PiS, the vote split between right-wing and liberal-wing, as well as old $v s$ new parties, we used the data that comes from National Electoral Commission (PKW) and Local Data Bank of Statistics Poland. 
Table 2. List of poviat-level explanatory variables used in regression analysis

\begin{tabular}{|c|c|}
\hline FINANCIAL & DEVELOPMENT \\
\hline $\begin{array}{l}\text { PIT revenues per capita }-\mathbf{H 1 . 4} \\
\text { CIT revenues per capita }-\mathbf{H 1 . 4} \\
\text { Coal mining tax revenues per capita } \\
\text { Debt service expenditure per 1k PLN revenue } \\
\text { Dynamics of PIT revenues per capita ( } 2015 \mathrm{vs} \\
\text { 2007) - H1.1 } \\
\text { Dynamics of CIT revenues per capita ( } 2015 \mathrm{vs} \\
\text { 2007) - H1.1 }\end{array}$ & $\begin{array}{l}\text { EU funds per capita }-\mathbf{H 1 . 5} \\
\text { Enterprise investment per } 1 \text { inhabitant } \\
\text { Enterprise capital per } 1 \text { inhabitant } \\
\text { Share of investment spending by local government } \\
\text { Fixed capital in industry per capita }\end{array}$ \\
\hline STRUCTURE OF THE ECONOMY & NATURAL CONDITIONS \\
\hline $\begin{array}{l}\text { Share of employment in agriculture - H1.3 } \\
\text { Share of employment in construction } \\
\text { Share of employment in financial sector }-\mathbf{H 1 . 4} \\
\text { Share of employment in other services - H1.4 }\end{array}$ & $\begin{array}{l}\text { Density of population } \\
\text { Share of urban population } \\
\text { City with poviat rights (big cities) - H1.4 } \\
\text { Distance to the voivodship capital } \\
\text { Spending due to natural disasters }\end{array}$ \\
\hline SOCIO-CULTURAL & SURFACE TREND / HISTORICAL \\
\hline $\begin{array}{l}\text { Divorce per } 1000 \text { inhabitants } \\
\text { Marriages per } 1000 \text { inhabitants aged 18-49 } \\
\text { Crimes per capita }\end{array}$ & $\begin{array}{l}\text { Longitude }^{*} \\
\text { Latitude }^{*} \\
\text { Historical Prussian partition } \\
\text { Historical Russian partition }\end{array}$ \\
\hline EDUCATION & DEMOGRAPHICAL STRUCTURE \\
\hline $\begin{array}{l}\text { High school education (number per capita) } \\
\text { Students per capita } \\
\text { Educational subsidy per capita } \\
\text { Children in kindergartens aged 3-5 per } \\
\text { inhabitants aged 18-49- H1.2 } \\
\text { Children in kindergartens aged 3-5 per place - } \\
\text { H1.2 }\end{array}$ & $\begin{array}{l}\text { Share of pre-working age population }-\mathbf{H 1 . 2} \\
\text { Children aged }<14 \text { per inhabitants aged } 18-49- \\
\text { H1.2 } \\
\text { Share of post-working population: men }-\mathbf{H 1 . 2} \\
\text { Share of post-working population: women }-\mathbf{H 1 . 2} \\
\text { Share of women } \\
\text { Children benefit }- \text { H1.2 }\end{array}$ \\
\hline LABOUR MARKET & DEMOGRAPHY \\
\hline $\begin{array}{l}\text { Workers per } 1000 \text { population - H1.4 } \\
\text { Dynamics of workers per } 1000 \text { population (2015 } \\
\text { vs 2007) - H1.1 } \\
\text { Monthly average gross salary - H1.4 } \\
\text { Registered unemployment rate } \\
\text { Share of unemployed below } 24 \text { years old among } \\
\text { unemployed } \\
\text { Share of long-term unemployed ( }>1 \text { year) } \\
\text { among unemployed } \\
\text { Share of unemployed with higher education } \\
\text { among unemployed } \\
\text { Activity rate - total - H1.4 } \\
\text { Activity rate - women }\end{array}$ & $\begin{array}{l}\text { Live births per } 1000 \text { inhabitants }-\mathbf{H 1 . 2} \\
\text { Deaths per } 1000 \text { inhabitants } \\
\text { Death share - cardiovascular } \\
\text { Death share - neoplasms } \\
\text { Death share - respiratory } \\
\text { Registered arrivals per capita } \\
\text { Migration balance per capita }\end{array}$ \\
\hline
\end{tabular}

* The longitude and latitude are representing the centroid of the region as the geometric center of its shape's projection on the plane. The symbols H1.1-H1.5 correspond to specific hypotheses discussed in Sections 2 and 3.

Source: own work, Local Data Bank, National Electoral Commission. 
As dependent variables, we chose the results (in \%) of particular election committees, i.e. PiS, K15, PO and N, as well as the turnout level. Moreover, 4 aggregate variables were created: (1) the percentage share of votes cast for K15 in the total number of votes for K15 and PiS (to look into the propensity to vote for the newcomer on the right wing), (2) the percentage share of votes cast for $\mathrm{N}$ in the total number of votes cast for $\mathrm{N}$ and $\mathrm{PO}$ (to look into the propensity to select the newcomer in the liberal segment), (3) the percentage share of votes cast both for PiS and K15 (as an aggregate right-wing measure) and (4) the percentage share of votes cast both for $\mathrm{N}$ and $\mathrm{K} 15$ (as an aggregate measure of propensity to vote for the newcomers).

Focusing on the parties' programmes, the way that they framed the election campaign rhetorically, as well as based on the election behaviour literature discussed in Section 2, we selected 54 out of approximately 360 poviat-level variables from the Local Data Bank provided by Statistics Poland that most likely determine the election behaviour (see Table 2).

Trying to explain the voting results and the victory of PiS, we need to take into account its sharp criticism of the incumbent government (formed by PO and PSL since 2007) and a series of attractive (but potentially very costly) election promises. Due to the fact that PiS accused the previous government of anti-development policy and of focusing on driving fast growth exclusively in large cities and their neighbourhoods, we hypothesize (H1.1) that the local economic dynamics from 2007 to 2015 (understood as the dynamics of PIT revenues, CIT revenues and workers per 1000 population) may have affected the voting results in such a way that the population of slow-growing poviats preferred to cast their votes on PiS, while the fast-growing poviats supported the incumbent party. Since the core poviats may have been sharing the profits from the high growth with the nearby peripheries via e.g. wages of commuters, spatial linkages are hypothesised here as well.

The introduction of additional child benefit - the 500+ child support program and reversing the retirement age reform - were two most notable PiS pledges prioritized during the election campaign. Therefore, in our analysis, we put emphasis on demographical variables, i.e. live births, children aged 14 and less per adult population aged $18-49$, as well as the share of pre- and post-working population, and expect their connection with with the voting results (H1.2). Moreover, the relationship between the demographic structure and the support for the particular parties allows us to examine if the belief that the support for right-wing parties is increasing with age holds in the Polish case.

Taking into consideration variables referring to the structure of the economy, the share of agriculture (understood as percentage of employees in the agricultural sector) is anticipatred to increase the support for PiS and K15 due to their election promise of introducing the law permitting the purchase of land exclusively by Polish farmers (H1.3). 
On the other hand, variables related to the economic activity, such as the employment per 1000 population and income from CIT or wealth of the inhabitants (approximated by income from PIT) are expected to positively influence the support for liberal parties ( $\mathrm{PO}$ and $\mathrm{N}$ ), especially for $\mathrm{N}$ which mainly targeted its programme to young voters with higher education and enrepreneurs interested in liberal economic policy (H1.4). In addition, due to the fact that the aforementioned parties are characterized by a pro-EU attitude, we are interested if EU fund absorption affects their results (H1.5).

Last, but not least, the dataset contains various cultural and historical factors, such as marriages per 1000 inhabitants aged 18-49, divorces per 1000 inhabitants, XIX-th century partitions, which possibly can explain the liberalism-conservativsm trade-off and refer to the theory that emphasizes the relevance of the partitions of Poland and the resulting historically shaped political attitudes.

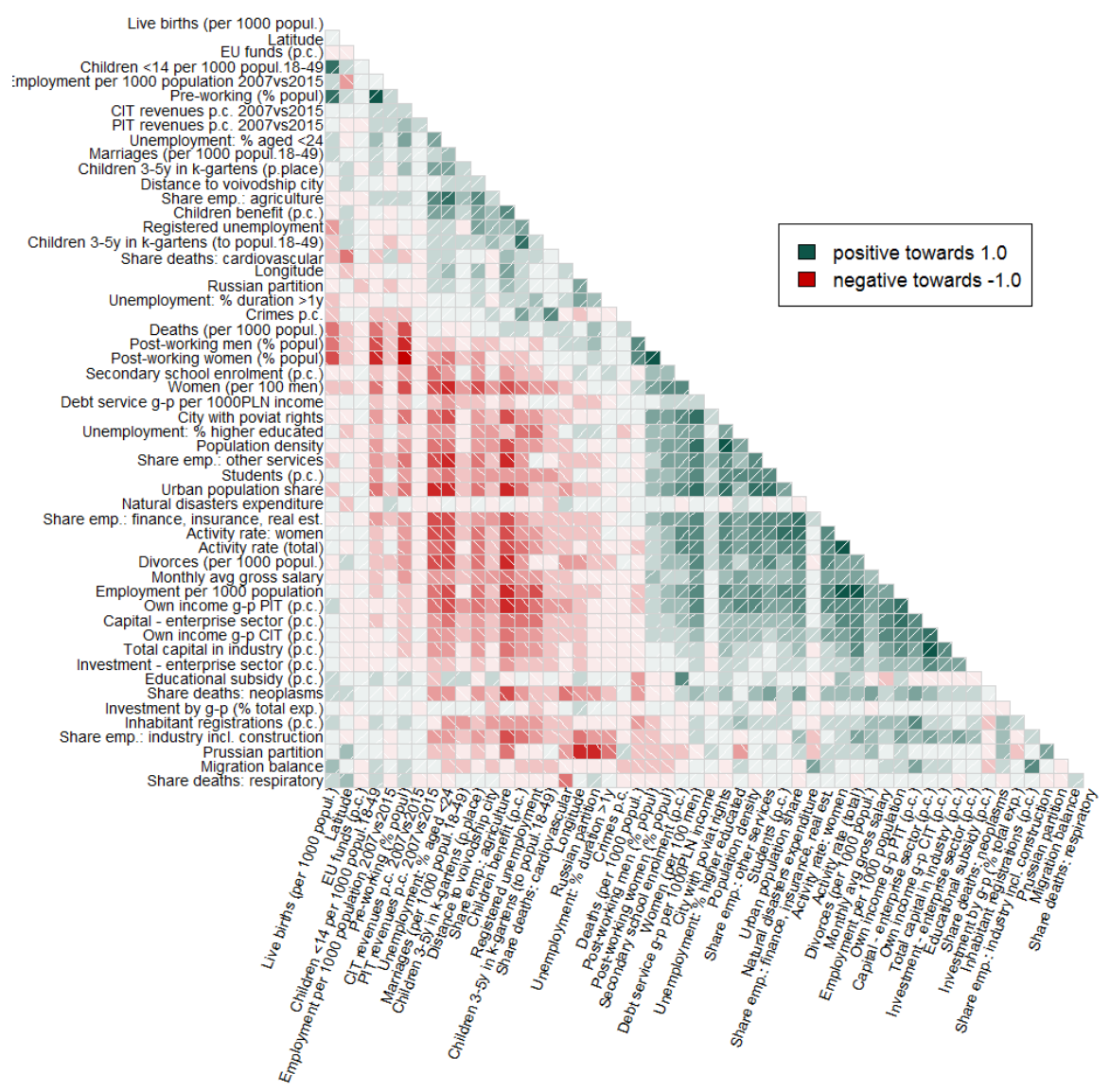

Fig. 2. Correlations between potential explanatory variables Source: own work, Local Data Bank - Statistics Poland (stat.gov.pl). 
Due to the fact that such a wide dataset is characterised by some collinearity (see Fig. 2), in order to obtain a proper set of variables, we apply two strategies:

1. General-to-specific modelling strategy (Campos, Ericsson, Hendry, 2003) and additionally, we used Bayesian model averaging (BMA) to confirm that models included all important variables indicated by BMA (Koop, 2003). The results presented in subsequent parts of the paper refer to specific (reduced) models. ${ }^{10}$

2. Principal component analysis based on the graphical screeplot criterion (see Fig. 4).
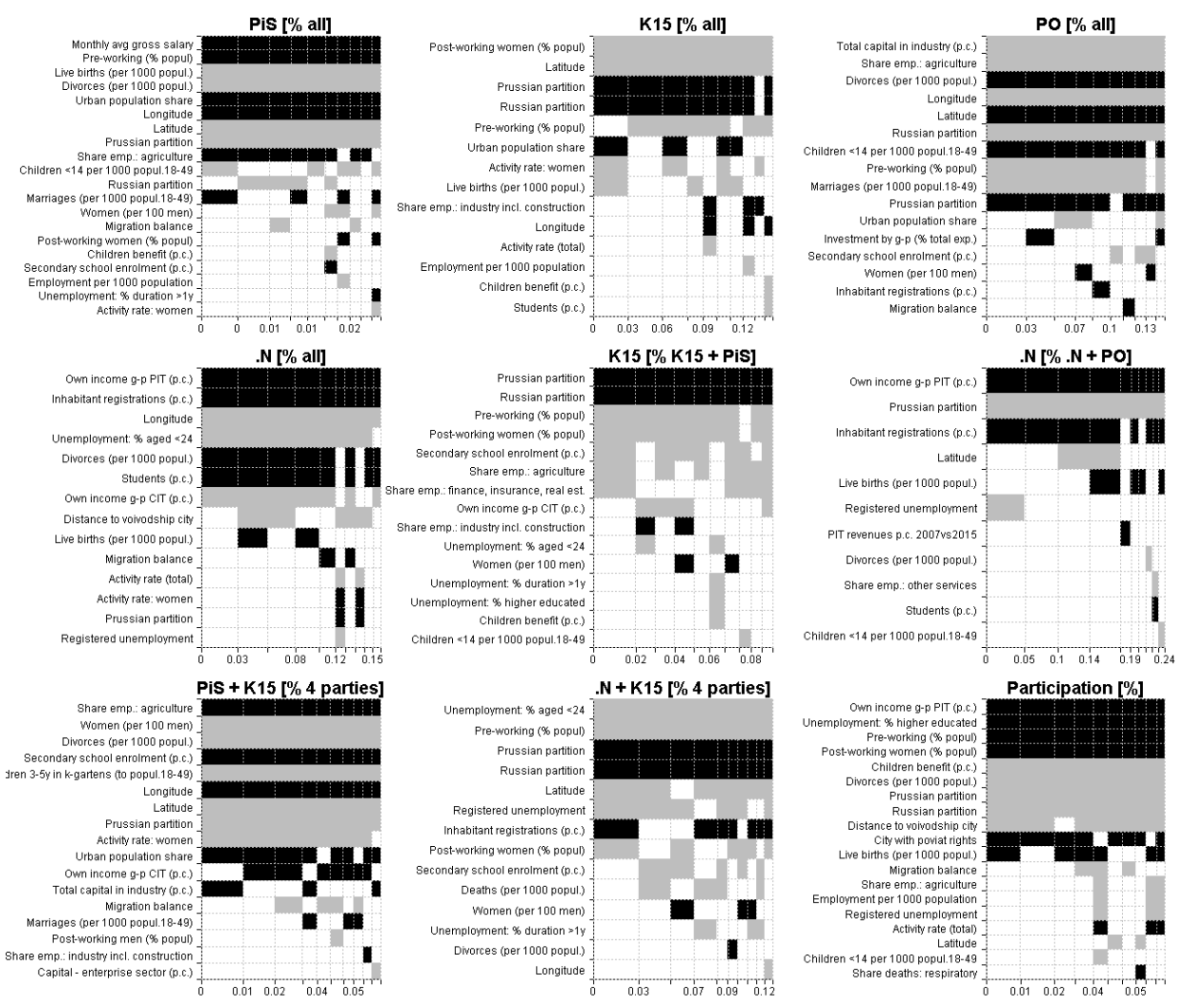

Fig. 3. Bayesian model averaging: regressor sets in best models [sign: black +, grey -]

Source: own work.

The application of the first strategy began with the linear, non-spatial regression. Based on its results, we constructed an initial set of determinants for the purpose of spatial specifications, for each dependent variable individually, com-

${ }^{10}$ Estimates from full (general) models available on request. 
prising of: (i) variables significant in consequent linear regressions (significance level 0.1), (ii) most likely regressors indicated by BMA (see Table 3 and Fig. 3), and (iii) four key variables by expert judgement: the longitude and latitude to control the surface trend, the employment rate per 1,000 population and the dummy for city with poviat rights (big cities).

Next, we extended the specification for each dependent variable in the spatial direction. It should be stressed that, in the presence of an omitted spatial data generating process, the non-spatial coefficients tend to be upward biased in the modulus if regressors are spatially autocorrelated themselves. As a result, the explanatory variables may spuriously appear as significant in linear regressions, and hence the initial sets are probably too wide and should be subject to further reduction.

Table 3. Model sizes with highest posterior likelihood under Bayesian model averaging

\begin{tabular}{|l|c|c|}
\hline \multicolumn{1}{|c|}{ Dependent variable } & Dominant model size & Model sizes with probability $>\mathbf{0 . 1}$ \\
\hline PiS & 15 & $13-17$ \\
\hline K15 & 8 & $7-10$ \\
\hline PO & 10 & $12-14$ \\
\hline N & 9 & $8-11$ \\
\hline K15 vs PiS & 8 & $7-11$ \\
\hline N vs PO & 5 & $4-6$ \\
\hline PiS+K15 & 13 & $12-15$ \\
\hline N+K15 & 9 & $8-11$ \\
\hline Participation & 17 & $15-18$ \\
\hline
\end{tabular}

Source: own work.

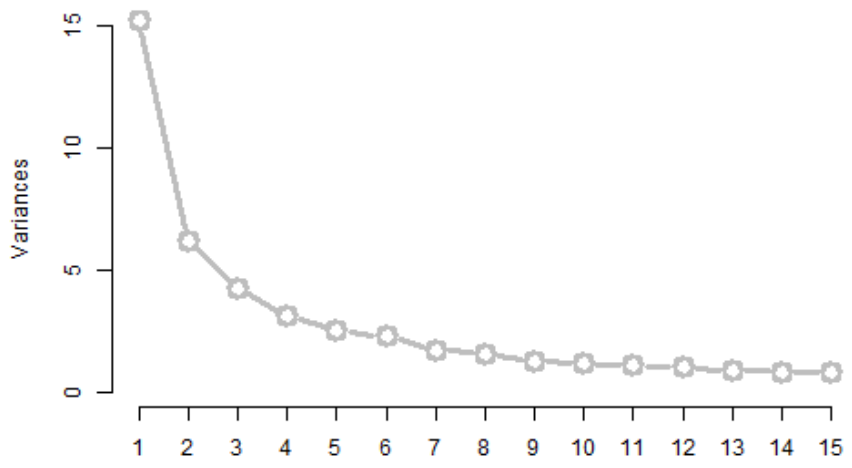

Fig. 4. Scree plot for principal components of the regressor set Source: own work. 
The second strategy consists of building principal components out of 54 variables under consideration. In line with the picture emerging from the screeplot criterion (see Fig. 4), two components were created (see Fig. 5):

- Factor 1 ("activity, employment, cities") consisted of variables related to the high labour market activity rate (in general and among women), relatively high employment in the service sector (as compared to the agriculture) and pointed to big cities with poviat rights and high population density. It appeared as predominantly related to high economic activity areas. Note the inverse relationship of the factor to high economic activity of the poviats (see the signs of loadings in Fig. 5).

- Factor 2 ("young") is based upon a set of demographic variables. The higher the component value, the younger the society.

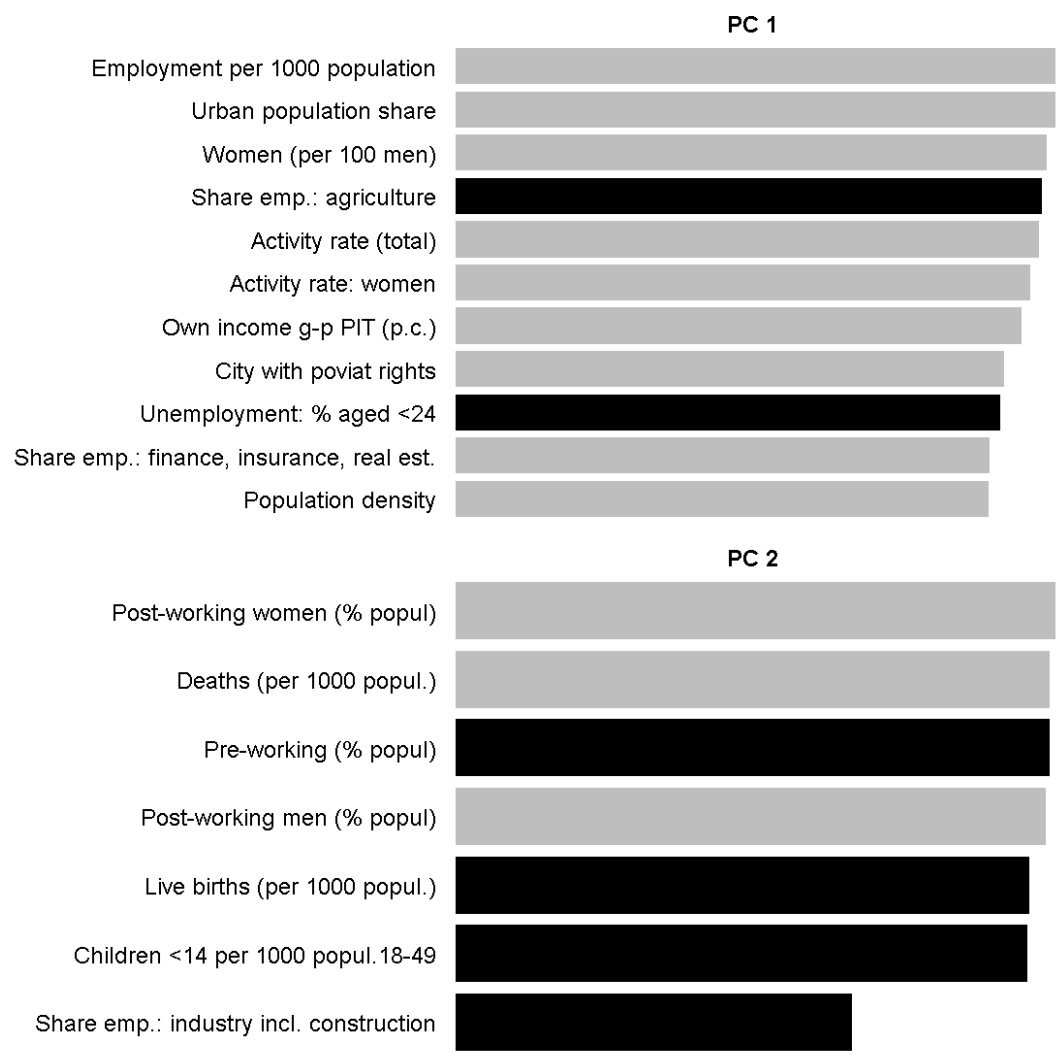

Fig. 5. Loadings and interpretation of principal components [sign: black + , grey -]

Source: own work. 
Having established the individual regressor sets for each of the dependent variables in question (both in terms of raw variables and principal components), we estimated the spatial models using the row-standardized $\boldsymbol{W}$ matrix based on geographic proximity (see Section 4). On top of that, we considered mixed- $\boldsymbol{W}$ specifications with an additional row-standardized matrix $\boldsymbol{W}$ indicating the adherence of two poviats to the same constituency. The inclusion of the latter matrix in the spatial error part stands for the latent effect of shared candidates within a group of poviats (Section 5).
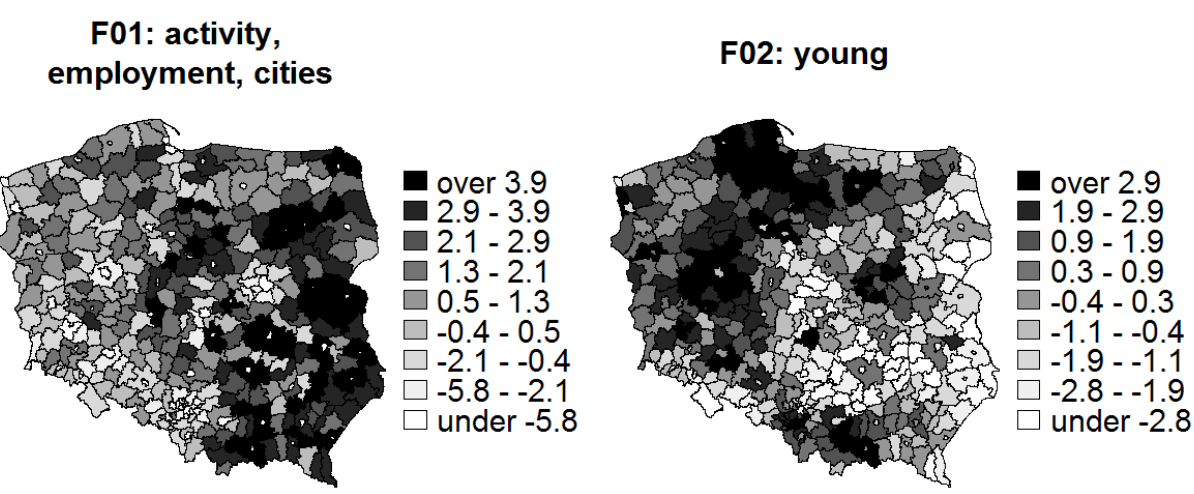

Fig. 6. Values of principal components for individual regions

Source: own work.

\section{EMPIRICAL RESULTS FOR SPATIAL SINGLE-SOURCE MODELS}

\subsection{Testing for spatial effects in linear regressions}

The results obtained for Moran's I and Lagrange multiplier tests indicated that the residuals from all linear regression specific models were spatially dependent (see Table 4; see also graphical inspection in Fig. 7). The robust versions of Lagrange multiplier tests indicated that, in 7 out of 9 models (except the one explaining voting participation and the outcome of $\mathrm{N}$ ), the linear model should be rejected against the alternative of the SLM model, but not SEM. A less obvious picture emerged for principal component models (see Table 5 and Fig. 8) and, in consequence, we inspected both SLM and SEM models, looking for the robustness of the results. 
Table 4. Testing of linear non-spatial regression specific (reduced) models

\begin{tabular}{|c|c|c|c|c|c|c|c|c|c|}
\hline Feature & $\begin{array}{c}\text { PiS } \\
{[\% \text { all }]}\end{array}$ & $\begin{array}{c}\text { K15 [\% } \\
\text { all] }\end{array}$ & $\begin{array}{c}\text { PO } \\
{[\% \text { all }]}\end{array}$ & $\mid \begin{array}{c}\mathrm{N} \\
{[\% \text { all }]}\end{array}$ & $\begin{array}{c}\text { K15 } \\
{[\% \text { K15 }} \\
+ \text { PiS }] \\
\end{array}$ & $\begin{array}{c}\mathbf{N} \\
{[\% \mathbf{N}+} \\
\mathbf{P O}]\end{array}$ & $\begin{array}{c}\text { PiS + } \\
\text { K15 [\% } 4 \\
\text { parties] }\end{array}$ & $\begin{array}{c}N+\text { K15 } \\
{[\% 4} \\
\text { parties] }\end{array}$ & $\begin{array}{c}\text { Partici- } \\
\text { pation } \\
{[\%]}\end{array}$ \\
\hline R-squared & 0.826 & 0.374 & 0.859 & 0.819 & 0.653 & 0.417 & 0.879 & 0.611 & 0.896 \\
\hline $\begin{array}{l}\text { Adjusted } \\
\text { R-squared }\end{array}$ & 0.813 & 0.344 & 0.852 & 0.810 & 0.632 & 0.394 & 0.873 & 0.589 & 0.889 \\
\hline $\begin{array}{l}\text { Breusch-Pagan } \\
\text { (p-value) }\end{array}$ & 0.095 & 0.999 & 0.083 & 0.186 & 0.841 & 0.258 & 0.038 & 0.812 & 0.023 \\
\hline $\begin{array}{l}\text { Jarque-Bera } \\
\text { (p-value) }\end{array}$ & 0.062 & 0.000 & 0.003 & 0.000 & 0.000 & 0.000 & 0.573 & 0.000 & 0.245 \\
\hline $\begin{array}{l}\text { Moran's I } \\
\text { (p-value) }\end{array}$ & 0.000 & 0.000 & 0.000 & 0.000 & 0.000 & 0.000 & 0.000 & 0.000 & 0.000 \\
\hline $\begin{array}{l}\text { LM: err } \\
\text { (p-value) }\end{array}$ & 0.000 & 0.000 & 0.000 & 0.000 & 0.000 & 0.000 & 0.000 & 0.000 & 0.000 \\
\hline $\begin{array}{l}\text { LM: lag } \\
\text { (p-value) }\end{array}$ & 0.000 & 0.000 & 0.000 & 0.000 & 0.000 & 0.000 & 0.000 & 0.000 & 0.000 \\
\hline $\begin{array}{l}\text { RLM: err } \\
\text { (p-value) }\end{array}$ & 0.424 & 0.291 & 0.280 & 0.056 & 0.123 & 0.788 & 0.237 & 0.737 & 0.005 \\
\hline $\begin{array}{l}\text { RLM: lag } \\
\text { (p-value) }\end{array}$ & 0.000 & 0.003 & 0.000 & 0.023 & 0.000 & 0.006 & 0.000 & 0.012 & 0.000 \\
\hline $\begin{array}{l}\text { SARMA } \\
\text { (p-value) }\end{array}$ & 0.000 & 0.000 & 0.000 & 0.000 & 0.000 & 0.000 & 0.000 & 0.000 & 0.000 \\
\hline AIC & 2264.23 & 1363.92 & 1951.78 & 1192.25 & 1935.65 & 2096.52 & 2253.62 & 1766.29 & 1660.54 \\
\hline
\end{tabular}

Source: own work.

It is noteworthy that some models exhibited exceptionally low R-squared (and adjusted R-squared) values. That was the case when explaining support for the new right-wing $\mathrm{K} 15$, and the choice between the liberal newcomer $\mathrm{N}$ and the incumbent PO. Those two variables may require additional clarification at the micro level, as the choice appears to be explicable on the individual level, rather than the regional one. One can conclude that the regional cross-section allows one to explain the election results to a decent extent as regards the results of well-established parties and the voting participation. This is, however, no truer for newly emerged parties that declare themselves as anti-establishment (K15) and/or are difficult to distinguish in the ideological or economic dimensions from their direct competitors ( $\mathrm{N}$ vs $\mathrm{PO}$ ).

The residuals of the spatial models reported here were not any more spatially autocorrelated (see Tables 6 and 8), and hence no need for considering dual-source models arose (except the additional hypothesis tested in Section 5). 


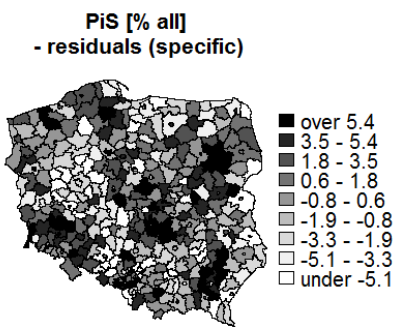

.N [\% all]

- residuals (specific)

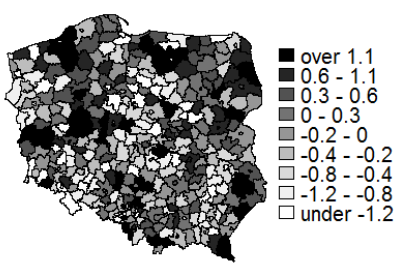

Pis + K15 [\% 4 parties]

- residuals (specific)

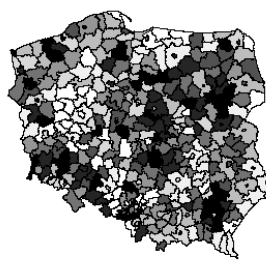

K15 [\% all]

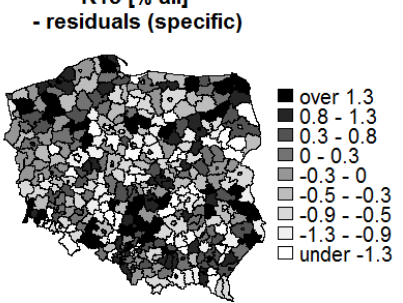

K15 [\% K15 + PiS ]

- residuals (specific)

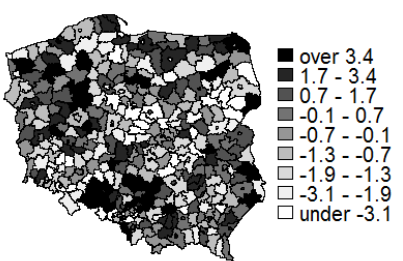

$. \mathrm{N}+\mathrm{K} 15[\% 4$ parties]

- residuals (specific)

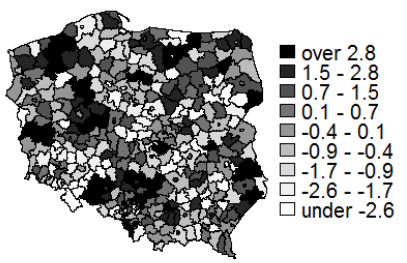

PO [\% all]

- residuals (specific)

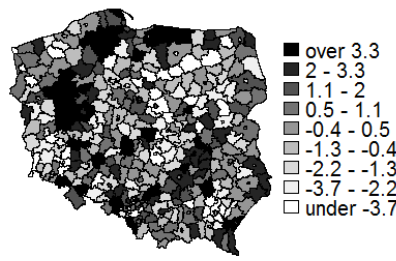

$\mathrm{N}[\% . \mathrm{N}+\mathrm{PO}]$

- residuals (specific)

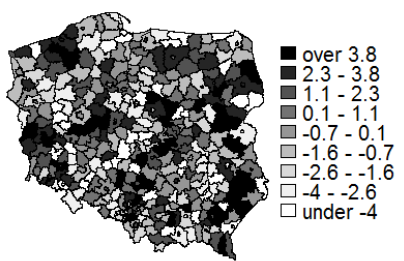

Participation [\%]

- residuals (specific)

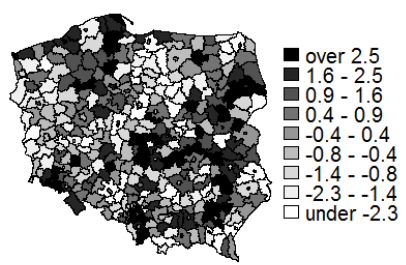

Fig. 7. Residuals from specific (reduced) models - spatial distribution

Source: own work.

Table 5. Testing of linear non-spatial regression models on principal components

\begin{tabular}{|l|c|c|c|c|c|c|c|c|c|}
\hline \multicolumn{1}{|c|}{ Feature } & $\begin{array}{c}\text { PiS } \\
{[\% \text { all }]}\end{array}$ & $\begin{array}{c}\text { K15 } \\
{[\% \text { all }]}\end{array}$ & $\begin{array}{c}\text { PO } \\
{[\% \text { all }]}\end{array}$ & $\begin{array}{c}\mathbf{N} \\
{[\% \text { all }]}\end{array}$ & $\begin{array}{c}\text { K15 } \\
{[\% \text { K15 + }} \\
\text { PiS }]\end{array}$ & $\begin{array}{c}\mathbf{N} \\
{[\%+\mathbf{N}+} \\
\text { PO }]\end{array}$ & $\begin{array}{c}\text { PiS + } \\
\text { K15 [\% 4 4 } \\
\text { parties }]\end{array}$ & $\begin{array}{c}\mathbf{N}+\text { K15 } \\
{\left[\begin{array}{c}\text { [\% 4 } \\
\text { parties }]\end{array}\right.}\end{array}$ & $\begin{array}{c}\text { Partici- } \\
\text { pation } \\
{[\%]}\end{array}$ \\
\hline R-squared & 0.257 & 0.008 & 0.406 & 0.619 & 0.123 & 0.072 & 0.433 & 0.308 & 0.397 \\
\hline $\begin{array}{l}\text { Adjusted } \\
\text { R-squared }\end{array}$ & 0.253 & 0.003 & 0.403 & 0.617 & 0.119 & 0.067 & 0.429 & 0.305 & 0.394 \\
\hline $\begin{array}{l}\text { Breusch-Pagan } \\
\text { (p-value) }\end{array}$ & $\mathbf{0 . 0 0 2}$ & 0.367 & $\mathbf{0 . 0 4 5}$ & $\mathbf{0 . 0 0 0}$ & 0.599 & 0.412 & $\mathbf{0 . 0 3 0}$ & 0.919 & $\mathbf{0 . 0 0 0}$ \\
\hline $\begin{array}{l}\text { Jarque-Bera } \\
\text { (p-value) }\end{array}$ & 0.213 & $\mathbf{0 . 0 0 0}$ & $\mathbf{0 . 0 3 1}$ & $\mathbf{0 . 0 0 0}$ & $\mathbf{0 . 0 0 0}$ & $\mathbf{0 . 0 0 0}$ & 0.620 & $\mathbf{0 . 0 0 0}$ & 0.267 \\
\hline $\begin{array}{l}\text { Moran's I } \\
\text { (p-value) }\end{array}$ & $\mathbf{0 . 0 0 0}$ & $\mathbf{0 . 0 0 0}$ & $\mathbf{0 . 0 0 0}$ & $\mathbf{0 . 0 0 0}$ & $\mathbf{0 . 0 0 0}$ & $\mathbf{0 . 0 0 0}$ & $\mathbf{0 . 0 0 0}$ & $\mathbf{0 . 0 0 0}$ & $\mathbf{0 . 0 0 0}$ \\
\hline $\begin{array}{l}\text { LM: err } \\
\text { (p-value) }\end{array}$ & $\mathbf{0 . 0 0 0}$ & $\mathbf{0 . 0 0 0}$ & $\mathbf{0 . 0 0 0}$ & $\mathbf{0 . 0 0 0}$ & $\mathbf{0 . 0 0 0}$ & $\mathbf{0 . 0 0 0}$ & $\mathbf{0 . 0 0 0}$ & $\mathbf{0 . 0 0 0}$ & $\mathbf{0 . 0 0 0}$ \\
\hline
\end{tabular}


Table 5. (cont.)

\begin{tabular}{|l|c|c|c|c|c|c|c|c|c|}
\hline $\begin{array}{l}\text { LM: lag } \\
\text { (p-value) }\end{array}$ & $\mathbf{0 . 0 0 0}$ & $\mathbf{0 . 0 0 0}$ & $\mathbf{0 . 0 0 0}$ & $\mathbf{0 . 0 0 0}$ & $\mathbf{0 . 0 0 0}$ & $\mathbf{0 . 0 0 0}$ & $\mathbf{0 . 0 0 0}$ & $\mathbf{0 . 0 0 0}$ & $\mathbf{0 . 0 0 0}$ \\
\hline $\begin{array}{l}\text { RLM: err } \\
\text { (p-value) }\end{array}$ & $\mathbf{0 . 0 9 9}$ & $\mathbf{0 . 0 0 0}$ & $\mathbf{0 . 0 0 9}$ & 0.959 & 0.541 & $\mathbf{0 . 0 0 2}$ & $\mathbf{0 . 0 0 1}$ & 0.995 & $\mathbf{0 . 0 0 0}$ \\
\hline $\begin{array}{l}\text { RLM: lag } \\
\text { (p-value) }\end{array}$ & $\mathbf{0 . 0 0 0}$ & $\mathbf{0 . 0 0 0}$ & $\mathbf{0 . 0 0 0}$ & $\mathbf{0 . 0 0 0}$ & $\mathbf{0 . 0 0 0}$ & 0.519 & $\mathbf{0 . 0 0 0}$ & $\mathbf{0 . 0 0 0}$ & 0.862 \\
\hline $\begin{array}{l}\text { SARMA } \\
\text { (p-value) }\end{array}$ & $\mathbf{0 . 0 0 0}$ & $\mathbf{0 . 0 0 0}$ & $\mathbf{0 . 0 0 0}$ & $\mathbf{0 . 0 0 0}$ & $\mathbf{0 . 0 0 0}$ & $\mathbf{0 . 0 0 0}$ & $\mathbf{0 . 0 0 0}$ & $\mathbf{0 . 0 0 0}$ & $\mathbf{0 . 0 0 0}$ \\
\hline AIC & 2766.902 & 1508.626 & 2465.000 & 1441.638 & 2249.445 & 2248.768 & 2808.470 & 1948.623 & 2282.693 \\
\hline
\end{tabular}

Source: own work.

Pis [\% all]

- residuals (PCA)

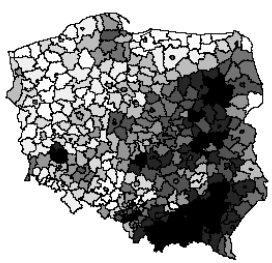

.N [\% all]

- residuals (PCA)

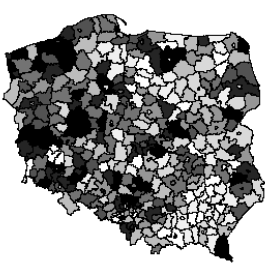

PiS + K15 [\% 4 parties]

- residuals (PCA)

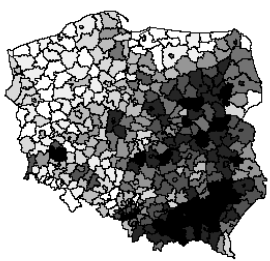

K15 [\% all]

- residuals (PCA)

over 12.1 $6.5-12.1$ $3.5-6.5$
$1.1-3.5$

$\square-2.8-1.1$

$-4.9--2.8$

$-7.3--4.9$

$-10.6--7.3$

$\square$ under -10.6
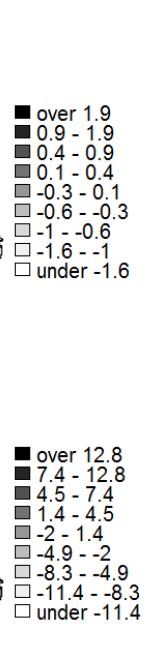

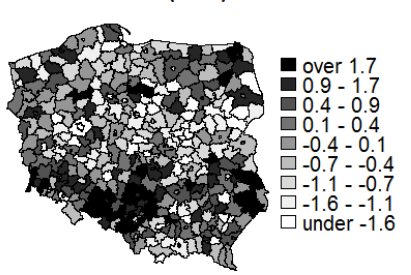

K15 [\% K15 + PiS]

- residuals (PCA)

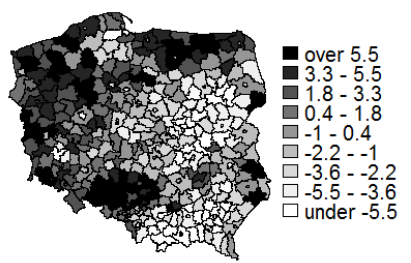

.N + K15 [\% 4 parties]

- residuals (PCA)

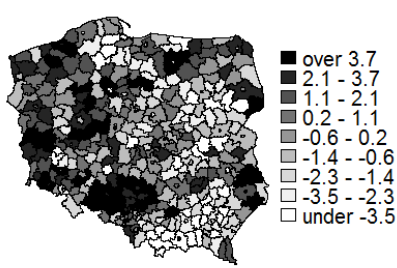

PO [\% all]

- residuals (PCA)

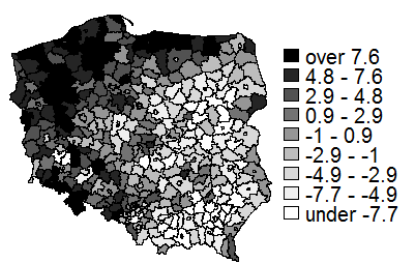

.N [\% .N + PO]

- residuals (PCA)

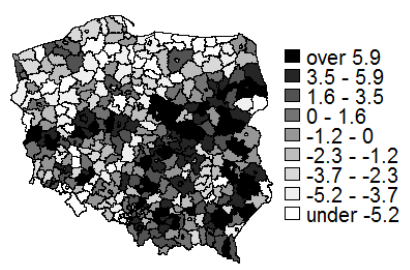

Participation [\%]

- residuals (PCA)

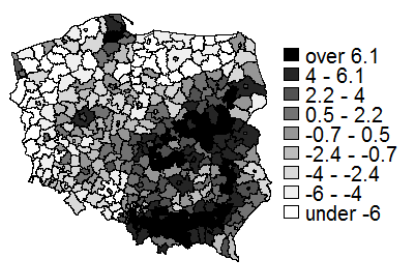

Fig. 8. Residuals from models on principal components - spatial distribution

Source: own work. 


\subsection{What does explain voting results? Single-source spatial models with principal components and reduced sets of variables}

Tables 6 and 8 provide information about the spatial models estimated with individual variables and principal components on the right-hand side, respectively: ${ }^{11}$

$$
\begin{array}{ll}
\text { SLM: } & y_{j}=\rho_{j} W y_{j}+x_{j} \beta_{j}+\varepsilon_{j} ; \\
\text { SEM: } & y_{j}=x_{j} \beta_{j}+\left(I-\lambda_{j} W\right)^{-1} \varepsilon_{j} .
\end{array}
$$

with $\boldsymbol{y}_{\boldsymbol{j}}$ - dependent variable in the $j$-th model, $\boldsymbol{x}_{\boldsymbol{j}}$ - the respective set of regressors in the $j$-th model, $\boldsymbol{\beta}_{i}-$ structural coefficients (reported, along with $\rho_{i}$ and $\lambda_{i}$, in Tables 6 and 8), $\boldsymbol{W}$ - spatial weight matrix based on shared border criterion. For robustness check, we also consider two additional $\boldsymbol{W}$ matrices: (i) defining neighbours as poviats whose centroids are located no further than $60 \mathrm{~km}$ away from each other, (ii) based on inverse distance (in $\mathrm{km}$ ).

Firstly, the component of economic activity (Factor 1) can be interpreted quite intuitively. It positively influenced the turnout level, as well as the support for liberal parties, especially for N. Then again, it contributed to a decrease in support for PiS and K15 (H1.4 generally confirmed). However, in the case of K15, the spatial model was needed to state this dependency (not confirmed in the linear setup). Interestingly, the factor representing the economic activity was not related to the traditional east-west division along the former borders of Poland's partitions in the $19^{\text {th }}$ century.

Considering individual variables of the component, one can arrive at the following conclusions:

- The share of agriculture (understood as percentage of employees in the agricultural sector) had a visible, positive impact on the support for PiS, but not K15. The share of agriculture negatively affected the result of PO, but not $\mathrm{N}$ (the latter may have competed against the agrarian party PSL, the former coalition member with PO, to a lesser extent). Hence, H1.3 and $\mathbf{H 3}$ may be viewed as partly confirmed.

- In Poland, the share of people under 24 in the total number of the unemployed in 2015 was $15.1 \%$. The lowest share was recorded for Warsaw $(5.3 \%)$, whereas the highest for poviat proszowicki near Krakow (30\%). While, unsurpris-

\footnotetext{
${ }^{11}$ Alternative estimates, i.a. using SEM / SLM (where not provided here) and SARAR specifications, are available upon request. There is no qualitative difference between SLM and SEM results, regarding the significance of variables, in a vast majority of cases. In case of the model for participation rate, since Lagrange multiplier tests did not favour SLM or SEM models, all 3 estimate sets are shown (OLS, SLM, SEM). However, in the case of SLM, Moran I test continues to show spatial dependencies so SEM appears to be preferable.
} 
ingly, unemployment among young people influenced the support for PiS as the runner-up, it turns out to weaken the support for both newcomers on the political scene, both on aggregate and as compared to their direct competitors ( $\mathrm{N}$ vs PO, $\mathrm{K} 15 \mathrm{vs} \mathrm{PiS}-\mathbf{H} \mathbf{3}$ partly confirmed). Although it may be viewed as a sign of young people rebelling against the authorities, one must admit that this phenomenon is very limited in Poland and the variable might in fact approximate another phenomenon, i.e. the generally passive attitude of young voters towards politics in some regions.

- The wealth of the inhabitants (approximated per PIT tax income) increased mainly the result of $\mathrm{N}$ and the turnout level. It did not increase the support for PO, which can be treated as result of weariness among more affluent people with the establishment. It turns out that the variable did not impair PiS.

- Against the expected outcome, the fact that a poviat was a city with poviat rights (i.e. a big city) did not decrease the share of votes for both right-wing parties, and at the same time weakened the results of PO. It possible that geography patterns are not the same as wealth distribution and, after accounting for wealth explicitly, it appeared that the anti-establishment sentiment wave may had appeared in big, but less wealthy cities. Still, in line with the previous literature, the voting turnout tends to be significantly higher in big cities.

- Contrary to how the whole component of economic activity works, the employment per 1,000 population weakened the turnout level. At the same time, the voter turnout was strengthened by the unemployment among people with higher education. Thus, it suggests a political activation of regions which abounded in economically inactive people and specific groups of the unemployed. The total unemployment indeed diminisheed the turnout, as less educated people, registered as short-term unemployed, often work abroad.

Secondly, looking at the impact of Factor 2, poviats with younger demographic profile of the residents noted higher voter turnout and support for the liberal party N. Furthermore, the transition from the linear to the spatial model caused that the negative impact on PiS - as well as the positive on PO - ceased to be significant. That suggested that the spatial clustering of Factor 2 (see Fig. 6) approximated the spatial effects arising elsewhere. A closer look at the individual variables building up this factor demonstrated, however, that the impact of demographics was more nuanced.

- Inhabitant registration, which reflects the population inflow to selected poviats, had a positive influence on the results of the new parties (part of H3).

- In poviats with many live births, there was no significant increase in support for PiS; on the contrary, the variable weakened its results. That suggests that election promises regarding the additional child benefit, widely considered as the main driver of their electoral success, could convince the socially oriented electorate, but not necessarily people in the childbearing age. This insight was confirmed by the other variables with similar information content, i.e. children aged 14 and 
less per adult population aged $18-49$, as well as children benefit amount per capita. Note that this aspect of demography remained neutral for the liberal parties. Surprisingly, this leads us to rejection of the hypothesis H1.2.

- The share of pre and post-working population had a positive influence on the result of PiS and the turnout level, and a negative one on the new parties. One could conclude that the relationship between age and the support for the winner party was non-linear, and hence the previous belief (see Cornelis et al., 2009; Truett, 1993; Wilson, 1973) that the support for right-wing conservative parties increases with age could be negated in the case of Poland's 2015 parliamentary election.

Cultural and historical factors (post-German territories, higher crime and divorce rates as compared to more conservative territories) had some predictive power in terms of the liberalism-conservatism trade-off, but the $19^{\text {th }}$ century partitions or pure surface trend by no means play the dominant role in explaining this dichotomy. Although the decrease in latitude appears to support the right-wing parties, some liberal ones $(\mathrm{N})$ do not necessarily gain when moving to the North. Overall, the new parties do not fit into the old electoral geographical schemes when taking into account the signs and significance of the last 4 variables in Tables 6 and 8 .

- Divorces per 1,000 population can be treated as symptomatic for moral liberalism prevailing in some poviats. As expected, the variable strengthened the shares of liberal parties, but also for the right-wing newcomer K15 (perhaps as a possible alternative to PiS for voters that were, for some reason, inclined to support the right-wing but were reluctant to adopt an ideologically conservative perspective).

- Conversely, the rate of marriages (computed against the population aged 18-49) increased, on average, the support for PiS and decreased for PO.

It must be emphasised that $\mathbf{E} \mathbf{U}$ fund absorption in a given poviat had surprisingly no effect on the election results in any of the analysed dimensions (rejection of H1.5). Looking at Fig. 2, this phenomenon cannot be explained by strong collinearity with any other variable. This suggested that the very fact of implementing EU policies was neutral to the local election outcomes, but perhaps the effects of these policies, as measured by other socio-economic variables, were relevant. However, there was some effect of local investment activity (by gminas and poviats) in the expected dimension, i.e. in favour of the incumbent PO.

Also, surprisingly, the local economic dynamics from 2007 to 2015 did not at all affect the voting results. This variable had never appeared as significant, for any dependent variable. Against our previously stated hypothesis, the population of slow-growing poviats was probably not blaming the incumbent government, nor the fast-growing poviats did prefer the incumbent party. Other factors appeared to have dominated over this dimension (H1.1 rejected).

The alternative specifications of the $\boldsymbol{W}$ matrix in (1) and (2) leave all the above discussed conclusions unaffected. It must be emphasised that the first alternative version does not remove the spatial autocorrelation from the residuals for some 
dependent variables (including PiS, total right-wing score and participation). For the remaining dependent variables, a vast majority of conclusions regarding the significance holds (including all the essential, hypothesised relationships). With the second alternative $\boldsymbol{W}$, we rejected the null hypothesis in the Moran's test for all the variables (while the coefficients also remain qualitatively unaffected as compared to the base version). ${ }^{12}$

Table 6a. Spatial reduced models for 9 dependent variables $(\mathrm{N}=380)$

\begin{tabular}{|c|c|c|c|c|c|c|}
\hline \multirow{2}{*}{ Model } & \multicolumn{2}{|c|}{ PiS } & \multicolumn{2}{|c|}{ K15 } & \multicolumn{2}{|c|}{ PO } \\
\hline & OLS & SLM & OLS & SLM & OLS & SLM \\
\hline$\rho$ & & $0.514 * * *$ & & $0.398 * * *$ & & $0.484 * * *$ \\
\hline \multicolumn{7}{|l|}{$\lambda$} \\
\hline Constant & $64.852 * *$ & 32.93 & $53.822 * * *$ & $35.181 * * *$ & $-47.848 * * *$ & $-60.764 * * *$ \\
\hline Own income g-p PIT (p.c.) & & & $-0.001 * *$ & $-0.001 * * *$ & & \\
\hline Own income g-p CIT (p.c.) & & & & & & $-0.008 * *$ \\
\hline Total capital in industry (p.c.) & & & & & $-0.026 * * *$ & $-0.013 *$ \\
\hline Debt service g-p per 1000PLN income & & & $-0.036^{*}$ & & & \\
\hline Capital - enterprise sector (p.c.) & $0.031 * *$ & $0.018^{*}$ & & & & \\
\hline Investment by g-p (\% total exp.) & & & & & $0.06 * *$ & $0.064 * *$ \\
\hline Share emp.: agriculture & $13.043 * * *$ & $13.243 * * *$ & & & $-12.944 * * *$ & $-10.48 * * *$ \\
\hline $\begin{array}{l}\text { Share emp.: industry incl. } \\
\text { construction }\end{array}$ & & & $2.895 * * *$ & $2.652 * * *$ & & \\
\hline \multicolumn{7}{|l|}{ Share emp.: finance, insurance, real est. } \\
\hline Share emp.: other services & $17.311^{* * *}$ & $18.312 * * *$ & & & $7.118^{*}$ & \\
\hline \multicolumn{7}{|l|}{ Employment per 1000 population } \\
\hline Monthly avg gross salary & $0.002 * *$ & $0.002 * * *$ & & & & \\
\hline \multicolumn{7}{|l|}{ Registered unemployment } \\
\hline Unemployment: \% aged $<24$ & $23.099 * *$ & $16.233^{*}$ & $-5.347^{*}$ & $-5.508 * *$ & & \\
\hline Unemployment: $\%$ duration $>1 y$ & $0.137 * * *$ & $0.1 * * *$ & & & & \\
\hline Unemployment: \% higher educated & $0.197 * *$ & $0.226^{* * *}$ & & & & \\
\hline Activity rate (total) & & & $-5.617 * * *$ & $-4.736 * * *$ & & \\
\hline Activity rate: women & $-17.402 *$ & & & & & \\
\hline Children $<14$ per 1000 popul.18-49 & $-0.167 * * *$ & $-0.104 * * *$ & & & $0.092 * * *$ & \\
\hline Pre-working (\% popul) & $7.073 * * *$ & $4.798 * * *$ & $-0.397 * * *$ & $-0.393 * * *$ & $-2.007 * * *$ & \\
\hline \multicolumn{7}{|l|}{ Post-working men (\% popul) } \\
\hline Post-working women (\% popul) & $248.25 * * *$ & $158.512 * * *$ & $-64.024 * * *$ & $-49.954 * * *$ & & \\
\hline Women (per 100 men) & $-0.561 * * *$ & $-0.4 * *$ & & & $0.235^{* *}$ & $0.406^{* * *}$ \\
\hline Children benefit (p.c.) & $-2469.137 * *$ & $-1835.685^{*}$ & $-803.943 * * *$ & $-838.327 * * *$ & & \\
\hline Live births (per 1000 popul.) & $-1.253 * * *$ & $-0.839 * *$ & $-0.264 * *$ & & & \\
\hline Deaths (per 1000 popul.) & & & & & & \\
\hline
\end{tabular}

${ }^{12}$ Complete results available upon request. 
Table 6a. (cont.)

\begin{tabular}{|c|c|c|c|c|c|c|}
\hline \multirow{2}{*}{ Model } & \multicolumn{2}{|c|}{ PiS } & \multicolumn{2}{|c|}{ K15 } & \multicolumn{2}{|c|}{ PO } \\
\hline & OLS & SLM & OLS & SLM & OLS & SLM \\
\hline \multicolumn{7}{|l|}{ Share deaths: cardiovascular } \\
\hline Share deaths: neoplasms & & & & & $0.133^{*}$ & \\
\hline Share deaths: respiratory & $0.251^{*}$ & $0.207 *$ & & & & \\
\hline \multicolumn{7}{|l|}{ Inhabitant registrations (p.c.) } \\
\hline Migration balance & $-0.001 * *$ & $-0.001 * * *$ & & & & \\
\hline Divorces (per 1000 popul.) & $-4.608 * * *$ & $-3.584 * * *$ & & & $2.826^{* * *}$ & $2.661 * * *$ \\
\hline Marriages (per 1000 popul.18-49) & $0.731 * * *$ & $0.571^{* *}$ & & & $-0.515^{* * *} *$ & $-0.365 * * *$ \\
\hline Secondary school enrolment (p.c.) & $231.469 * * *$ & & & & $-72.22 * *$ & \\
\hline Educational subsidy (p.c.) & $-0.009 * * *$ & $-0.007 * * *$ & & & & \\
\hline Students (p.c.) & $-29.419 * *$ & $-34.423 * * *$ & & & & \\
\hline $\begin{array}{l}\text { Children 3-5y in k-gartens (to } \\
\text { popul.18-49) }\end{array}$ & & & & & & $33.817 * * *$ \\
\hline \multicolumn{7}{|l|}{ Population density } \\
\hline Urban population share & $0.082 * * *$ & $0.065^{* * *}$ & & & $-0.042 * *$ & \\
\hline City with poviat rights & & & $0.764 * *$ & & & $-1.21 * *$ \\
\hline \multicolumn{7}{|l|}{ Distance to voivodship city } \\
\hline Longitude & $0.708 * * *$ & & $0.162 * * *$ & $0.117 * *$ & $-0.563 * * *$ & $-0.213 * *$ \\
\hline Latitude & $-1.583 * * *$ & $-1.031 * * *$ & $-0.552 * * *$ & $-0.347 * * *$ & $1.173^{* * *}$ & $0.721^{* * *}$ \\
\hline Prussian partition & $-8.279 * * *$ & $-2.074 * *$ & $2.035 * * *$ & $1.272 * * *$ & $2.988^{* * *}$ & \\
\hline Russian partition & $-3.428 * * *$ & & $1.768 * * *$ & $1.321 * * *$ & $-3.017 * * *$ & $-2.264 * * *$ \\
\hline Moran's I (p-value) & 0 & 0.32 & 0 & 0.454 & 0 & 0.096 \\
\hline
\end{tabular}

Source: own work.

Table 6b. Spatial reduced models for 9 dependent variables $(\mathrm{N}=380)$

\begin{tabular}{|c|c|c|c|c|c|c|c|}
\hline \multirow{2}{*}{ Model } & \multicolumn{3}{|c|}{$\mathbf{N}$} & \multicolumn{2}{|c|}{ K15vsPiS } & \multicolumn{2}{|c|}{ NvsPO } \\
\hline & OLS & SLM & SEM & OLS & SLM & OLS & SLM \\
\hline$\rho$ & & $0.362 * * *$ & & & $0.422 * * *$ & & $0.449 * * *$ \\
\hline$\lambda$ & & & $0.543 * * *$ & & & & \\
\hline Constant & $5.688^{*}$ & $4.838^{*}$ & $14.862 * * *$ & $82.527 * * *$ & $60.689 * * *$ & $43.28 * * *$ & 11.317 \\
\hline Own income g-p PIT (p.c.) & $0.004 * * *$ & $0.003 * * *$ & $0.005 * * *$ & $-0.003 * *$ & $-0.003 * *$ & $0.004 * * *$ & $0.003 * * *$ \\
\hline \multicolumn{8}{|l|}{ Own income g-p CIT (p.c.) } \\
\hline \multicolumn{8}{|l|}{ Total capital in industry (p.c.) } \\
\hline $\begin{array}{l}\text { Debt service g-p per 1000PLN } \\
\text { income }\end{array}$ & & & & $-0.101 * *$ & $-0.077 * *$ & & \\
\hline \multicolumn{8}{|l|}{ Capital - enterprise sector (p.c.) } \\
\hline \multicolumn{8}{|l|}{ Investment by g-p (\% total exp.) } \\
\hline \multicolumn{8}{|l|}{ Share emp.: agriculture } \\
\hline $\begin{array}{l}\text { Share emp.: industry incl. } \\
\text { construction }\end{array}$ & & & & & & & \\
\hline
\end{tabular}


Table 6b. (cont.)

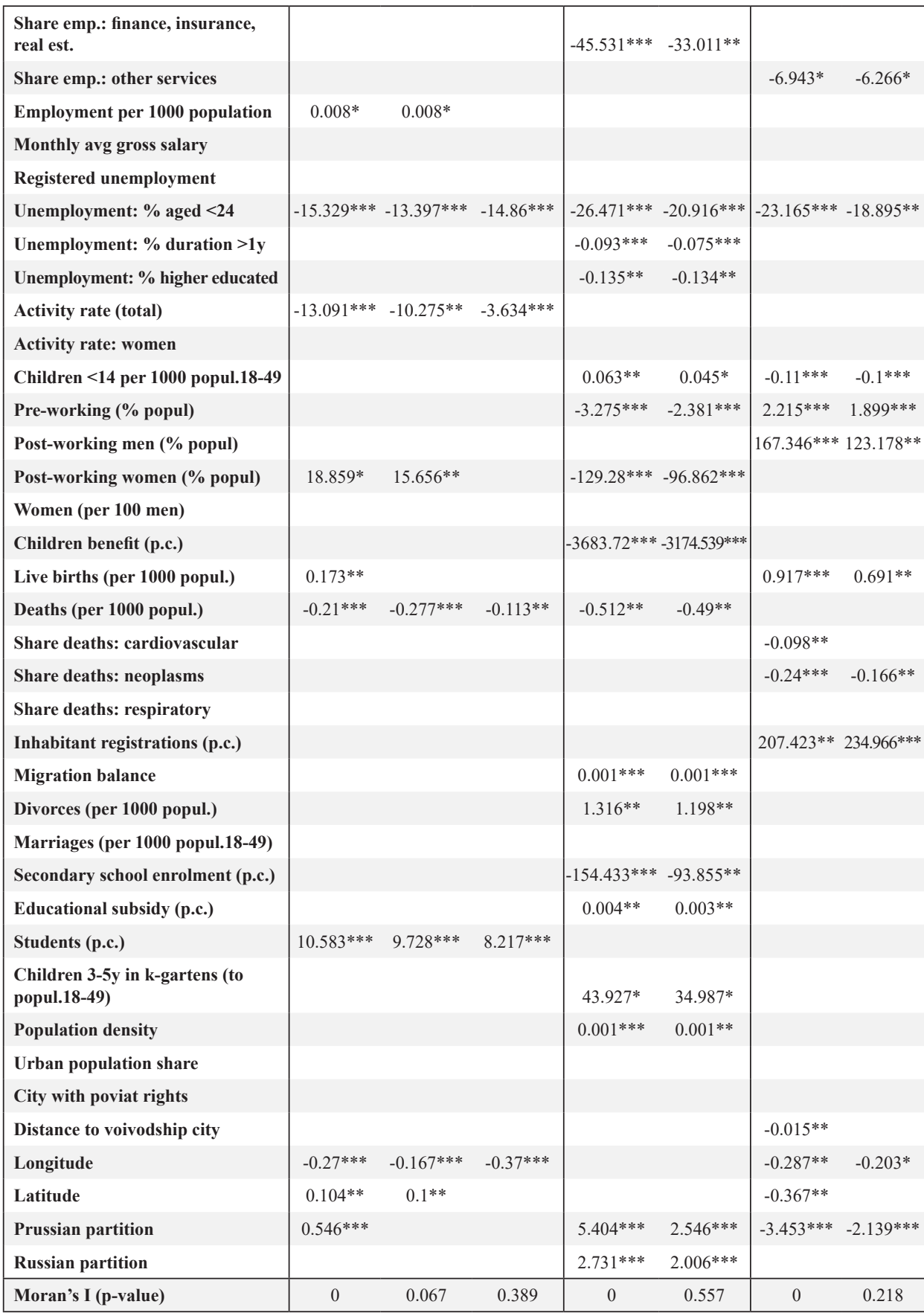

Source: own work. 
Table 6c. Spatial reduced models for 9 dependent variables $(\mathrm{N}=380)$

\begin{tabular}{|c|c|c|c|c|c|c|c|}
\hline \multirow{2}{*}{ Model } & \multicolumn{2}{|c|}{ PiS+K15 } & \multicolumn{2}{|c|}{ K15+N } & \multicolumn{3}{|c|}{ Participation } \\
\hline & OLS & SLM & OLS & SLM & OLS & SLM & SEM \\
\hline$\rho$ & & $0.493 * * *$ & & $0.404 * * *$ & & $0.283^{* * *}$ & \\
\hline$\lambda$ & & & & & & & $0.515 * * *$ \\
\hline Constant & $210.561 * * *$ & $124.584 * * *$ & * $62.594 * * *$ & $54.71 * * *$ & 0.936 & -6.02 & 8.178 \\
\hline Own income g-p PIT (p.c.) & & & & & $0.011 * * *$ & $0.007 * * *$ & $0.011 * * *$ \\
\hline Own income g-p CIT (p.c.) & $0.03 * * *$ & $0.019 * * *$ & & & & & \\
\hline \multicolumn{8}{|l|}{ Total capital in industry (p.c.) } \\
\hline $\begin{array}{l}\text { Debt service g-p per 1000PLN } \\
\text { income }\end{array}$ & & & & & $-0.055^{*}$ & $-0.049 *$ & \\
\hline \multicolumn{8}{|l|}{ Capital - enterprise sector (p.c.) } \\
\hline Investment by g-p (\% total exp.) & & & & & $0.049 * *$ & $0.033^{*}$ & \\
\hline Share emp.: agriculture & $21.17 * * *$ & $18.378 * * *$ & & & $-9.683 * * *$ & $-7.906 * * *$ & $-7.147 * * *$ \\
\hline \multicolumn{8}{|l|}{$\begin{array}{l}\text { Share emp.: industry incl. } \\
\text { construction }\end{array}$} \\
\hline \multicolumn{8}{|l|}{$\begin{array}{l}\text { Share emp.: finance, insurance, } \\
\text { real est. }\end{array}$} \\
\hline Share emp.: other services & & & $-10.107 * * *$ & $-6.626^{* *}$ & & & \\
\hline Employment per 1000 population & & & $0.025^{* *}$ & $0.02 * *$ & $-0.187 * * *$ & $-0.183 * * *$ & $-0.175 * * *$ \\
\hline Monthly avg gross salary & & $0.001 * *$ & & & $-0.001 *$ & & \\
\hline Registered unemployment & & & & & $-0.578 * * *$ & $-0.589 * * *$ & $-0.554 * * *$ \\
\hline Unemployment: $\%$ aged $<24$ & & & $-31.709 * * *$ & $-20.473 * * *$ & & & \\
\hline Unemployment: $\%$ duration $>1 y$ & & & $-0.064 * * *$ & $-0.047 * *$ & & & \\
\hline $\begin{array}{l}\text { Unemployment: \% higher } \\
\text { educated }\end{array}$ & & & $-0.141 * *$ & $-0.139 * * *$ & $0.27 * * *$ & $0.254 * * *$ & $0.263 * * *$ \\
\hline Activity rate (total) & & & $-41.653 * * *$ & $-21.933 * *$ & $167.453 * * *$ & $166.82^{* * *}$ & $159.439 * * *$ \\
\hline Activity rate: women & $-27.906 * * *$ & $-18.355 * * *$ & * $18.619 * *$ & & & & \\
\hline Children $<14$ per 1000 popul.18-49 & $-0.095 * * *$ & & & & $-0.079 * * *$ & $-0.048 * * *$ & $-0.058 * * *$ \\
\hline Pre-working (\% popul) & $3.164 * * *$ & $1.05 * * *$ & $-1.112 * * *$ & $-0.653 * * *$ & $3.465 * * *$ & $2.449 * * *$ & $2.912 * * *$ \\
\hline Post-working men (\% popul) & & & $97.433 *$ & & $124.338 * * *$ & & $145.567 * * *$ \\
\hline Post-working women (\% popul) & & & $-131.696^{* * *}$ & & $171.366^{* * * *}$ & $204.945 * * *$ & $157.347 * * *$ \\
\hline Women (per 100 men) & $-0.672 * * *$ & $-0.512 * * *$ & $0.245^{* *}$ & & & & \\
\hline Children benefit (p.c.) & & & & & $-2087.043 * * *$ & $-2086.594 * * *$ & $-1798.965 * * *$ \\
\hline Live births (per 1000 popul.) & $-1.34 * * *$ & $-0.772 * *$ & & & $0.703 * * *$ & $0.481 * * *$ & $0.567 * * *$ \\
\hline Deaths (per 1000 popul.) & & & $-0.372 *$ & $-0.69 * * *$ & & $-0.426 * * *$ & $-0.356 * *$ \\
\hline \multicolumn{8}{|l|}{ Share deaths: cardiovascular } \\
\hline \multicolumn{8}{|l|}{ Share deaths: neoplasms } \\
\hline Share deaths: respiratory & & & & & $0.154 * *$ & $0.105^{*}$ & $0.102 *$ \\
\hline Inhabitant registrations (p.c.) & & & $165.8^{* * *}$ & $178.424 * * *$ & & & \\
\hline Migration balance & $-0.001 * *$ & $-0.001 * * *$ & & & $-0.001 * * *$ & & $0 * * *$ \\
\hline Divorces (per 1000 popul.) & $-4.689 * * *$ & $-4.205 * * *$ & $1.142 * *$ & $0.94 * *$ & $-1.35 * * *$ & $-1.379 * * *$ & $-0.916^{* *}$ \\
\hline
\end{tabular}


Table 6c. (cont.)

\begin{tabular}{|c|c|c|c|c|c|c|c|}
\hline Marriages (per 1000 popul.18-49) & $0.905 * * *$ & $0.618 * * *$ & & & & & \\
\hline Secondary school enrolment (p.c.) & $196.78 * * *$ & & $-90.828 * *$ & & & & \\
\hline Educational subsidy (p.c.) & & & $0.003 * *$ & & $-0.002 * * *$ & $-0.002 * *$ & $-0.002 * * *$ \\
\hline Students (p.c.) & & & $11.833^{*}$ & $11.487^{*}$ & & & \\
\hline $\begin{array}{l}\text { Children 3-5y in k-gartens (to } \\
\text { popul.18-49) }\end{array}$ & $-62.46 * * *$ & $-47.45^{* * *}$ & & & & & \\
\hline \multicolumn{8}{|l|}{ Population density } \\
\hline Urban population share & $0.099 * * *$ & $0.07 * * *$ & & & & & \\
\hline City with poviat rights & & & & & $1.241 * *$ & $1.495 * * *$ & $1.111^{* *}$ \\
\hline Distance to voivodship city & & & & & $-0.011 * * *$ & & $-0.011 * *$ \\
\hline Longitude & $1.04 * * *$ & $0.373^{* *}$ & & & & & \\
\hline Latitude & $-2.215 * * *$ & $-1.349 * * *$ & $-0.56 * * *$ & $-0.358 * * *$ & $-0.375 * * *$ & $-0.202 *$ & $-0.411 * *$ \\
\hline Prussian partition & $-5.395 * * *$ & & $4.089 * * *$ & $1.878 * * *$ & $-3.331 * * *$ & $-2.06 * * *$ & $-2.481 * * *$ \\
\hline Russian partition & $3.233 * * *$ & $2.754 * * *$ & $3.576^{* * *}$ & $2.094 * * *$ & $-2.381 * * *$ & $-1.593 * * *$ & $-1.873 * * *$ \\
\hline Moran's I (p-value) & 0 & 0.16 & 0 & 0.168 & 0 & 0.013 & 0.653 \\
\hline
\end{tabular}

Source: own work.

Table 7a. Mixed-W reduced models for 9 dependent variables $(\mathrm{N}=380)$

\begin{tabular}{|c|c|c|c|c|c|c|}
\hline \multirow[b]{2}{*}{ Model } & \multicolumn{2}{|c|}{ PiS } & \multicolumn{2}{|c|}{ K15 } & \multicolumn{2}{|c|}{ PO } \\
\hline & $\begin{array}{l}\text { SARAR } \\
\text { mixed W }\end{array}$ & $\begin{array}{c}\text { SEM } \\
\text { mixed W }\end{array}$ & $\begin{array}{l}\text { SARAR } \\
\text { mixed W }\end{array}$ & $\begin{array}{c}\text { SEM } \\
\text { mixed } W\end{array}$ & $\begin{array}{l}\text { SARAR } \\
\text { mixed W }\end{array}$ & $\begin{array}{c}\text { SEM } \\
\text { mixed W }\end{array}$ \\
\hline$\rho($ base W) $/ \lambda$ (base W) & $0.444 * * *$ & $0.537 * * *$ & $0.356 * * *$ & $0.351 * * *$ & $0.409 * * *$ & $0.496^{* * *}$ \\
\hline$\lambda$ (constituency W) & $0.316^{* * *}$ & $0.17^{* *}$ & 0.15 & 0.112 & $0.283 * * *$ & $0.196 * * *$ \\
\hline Constant & 37.895 & $63.78 * *$ & $35.283 * * *$ & $48.823 * * *$ & $-59.277 * * *$ & $-60.497 * * *$ \\
\hline Own income g-p PIT (p.c.) & & & $-0.001 * *$ & $-0.001 * * *$ & & \\
\hline Own income g-p CIT (p.c.) & & & & & $-0.01 * * *$ & $-0.009 * * *$ \\
\hline \multicolumn{7}{|l|}{ Total capital in industry (p.c.) } \\
\hline Debt service g-p per 1000PLN income & & & & $-0.033^{*}$ & & \\
\hline Capital - enterprise sector (p.c.) & $0.017 *$ & $0.019^{*}$ & & & & \\
\hline Investment by g-p (\% total exp.) & & & & & $0.063 * *$ & $0.066^{* *}$ \\
\hline Share emp.: agriculture & $13.525^{* * *}$ & $11.999 * * *$ & & & $-9.25 * * *$ & $-11.873 * * *$ \\
\hline Share emp.: industry incl. construction & & & $2.385 * * *$ & $2.711 * * *$ & & \\
\hline \multicolumn{7}{|l|}{ Share emp.: finance, insurance, real est. } \\
\hline Share emp.: other services & $15.506^{* * *}$ & $13.418^{* *}$ & & & $5.673 *$ & $5.626^{*}$ \\
\hline \multicolumn{7}{|l|}{ Employment per 1000 population } \\
\hline Monthly avg gross salary & $0.002 * * *$ & $0.001 * *$ & & & & \\
\hline \multicolumn{7}{|l|}{ Registered unemployment } \\
\hline Unemployment: \% aged $<24$ & $21.068 * *$ & $36.196 * * *$ & $-5.61 * *$ & $-5.359^{*}$ & & \\
\hline Unemployment: $\%$ duration $>1 y$ & $0.091 * *$ & $0.101^{* * *}$ & & & & \\
\hline
\end{tabular}


Table 7a. (cont.)

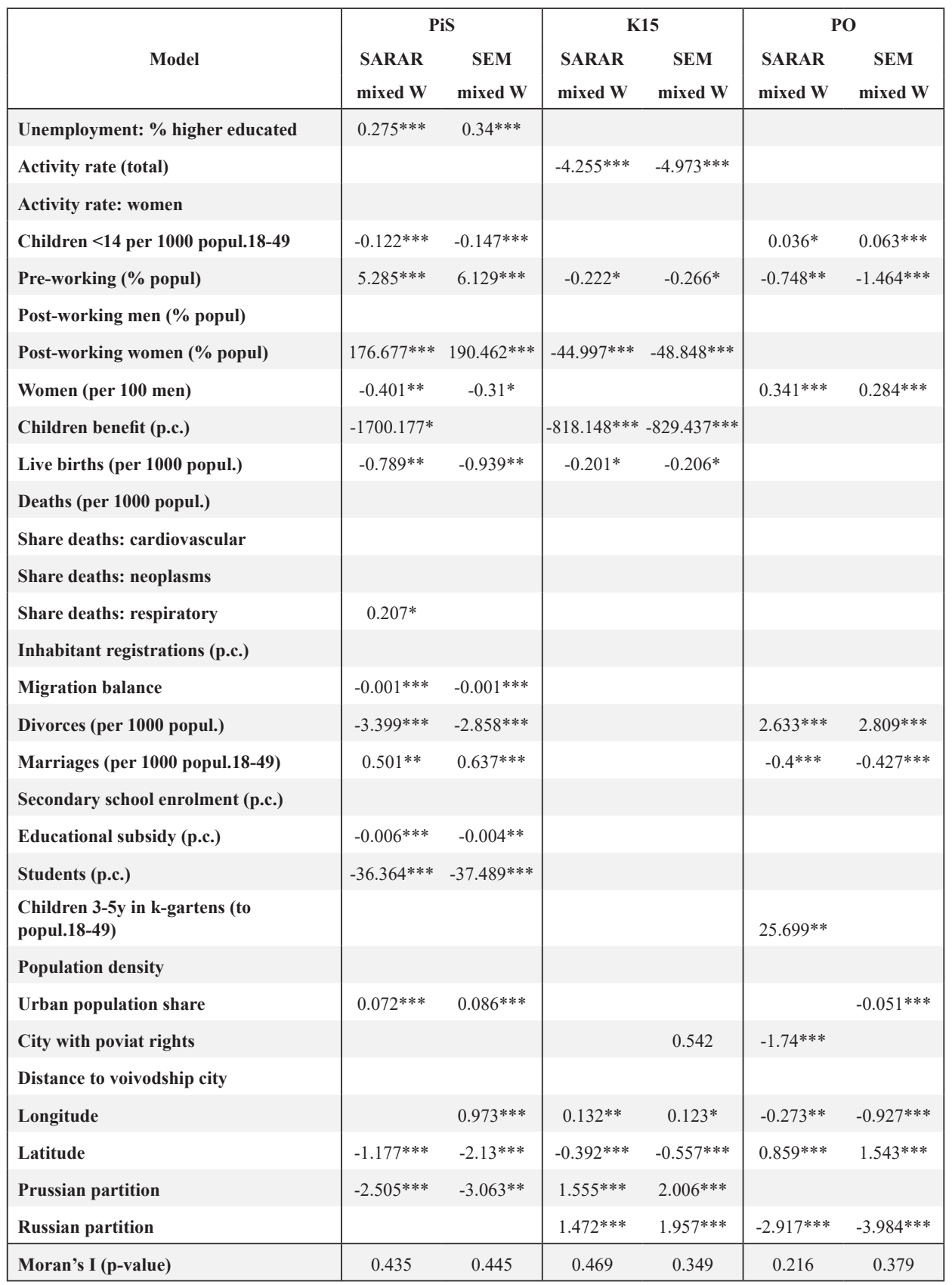

Source: own work. 
Table 7 b. Mixed-W reduced models for 9 dependent variables $(\mathrm{N}=380)$

\begin{tabular}{|c|c|c|c|c|c|c|}
\hline \multirow[b]{2}{*}{ Model } & \multicolumn{2}{|c|}{$\mathbf{N}$} & \multicolumn{2}{|c|}{ K15vsPiS } & \multicolumn{2}{|c|}{ NvsPO } \\
\hline & $\begin{array}{l}\text { SARAR } \\
\text { mixed W }\end{array}$ & $\begin{array}{c}\text { SEM } \\
\text { mixed W }\end{array}$ & $\begin{array}{l}\text { SARAR } \\
\text { mixed W }\end{array}$ & $\begin{array}{c}\text { SEM } \\
\text { mixed W }\end{array}$ & $\begin{array}{l}\text { SARAR } \\
\text { mixed W }\end{array}$ & $\begin{array}{c}\text { SEM } \\
\text { mixed W }\end{array}$ \\
\hline$\rho($ base $W) / \lambda$ (base W) & $0.342 * * *$ & $0.527 * * *$ & $0.347 * * *$ & $0.405 * * *$ & $0.349 * * *$ & $0.378 * * *$ \\
\hline$\lambda$ (constituency $\mathbf{W})$ & 0.103 & 0.031 & $0.32 * * *$ & $0.235 * * *$ & $0.392 * * *$ & $0.275^{* * *}$ \\
\hline Constant & $5.193^{*}$ & $14.832 * * *$ & $51.342 * * *$ & $61.888^{* * *}$ & 1.007 & 6.217 \\
\hline Own income g-p PIT (p.c.) & $0.003 * * *$ & $0.005 * * *$ & & & $0.004 * * *$ & $0.005 * * *$ \\
\hline Own income g-p CIT (p.c.) & & & & & & \\
\hline Total capital in industry (p.c.) & & & & & & \\
\hline Debt service g-p per 1000PLN income & & & & & & \\
\hline Capital - enterprise sector (p.c.) & & & & & & \\
\hline Investment by g-p (\% total exp.) & & & & & & \\
\hline Share emp.: agriculture & & & & & & \\
\hline Share emp.: industry incl. construction & & & & & & \\
\hline Share emp.: finance, insurance, real est. & & & $-27.29 * *$ & $-25.197^{*}$ & & \\
\hline Share emp.: other services & & & & & & \\
\hline Employment per 1000 population & $0.008^{*}$ & & & & & \\
\hline Monthly avg gross salary & & & & & & \\
\hline Registered unemployment & & & & & & \\
\hline Unemployment: $\%$ aged $<24$ & $-13.436 * * *$ & $-14.808 * * *$ & $-23.63 * * *$ & $-31.629 * * *$ & $-12.2 *$ & $-13.138^{*}$ \\
\hline Unemployment: $\%$ duration $>1 y$ & & & $-0.074 * * *$ & $-0.094 * * *$ & & \\
\hline Unemployment: \% higher educated & & & $-0.159 * * *$ & $-0.203 * * *$ & & \\
\hline Activity rate (total) & $-10.042 * *$ & $-3.657 * * *$ & & & & \\
\hline Activity rate: women & & & & & & \\
\hline Children $<14$ per 1000 popul.18-49 & & & & & $-0.096^{* * *}$ & $-0.105^{* * *}$ \\
\hline Pre-working (\% popul) & & & $-1.319 * * *$ & $-1.43 * * *$ & $2.476^{* * *}$ & $2.714 * * *$ \\
\hline Post-working men (\% popul) & & & & & $149.103 * *$ & $177.833^{* * *}$ \\
\hline Post-working women (\% popul) & $14.955^{*}$ & & $-96.617 * * *$ & $-98.761 * * *$ & & \\
\hline Women (per 100 men) & & & & & & \\
\hline Children benefit (p.c.) & & & $-2796.665 * * *$ & $-1843.92 * * *$ & & \\
\hline Live births (per 1000 popul.) & & & & & & \\
\hline Deaths (per 1000 popul.) & $-0.271 * * *$ & $-0.112 * *$ & & & & \\
\hline Share deaths: cardiovascular & & & & & & \\
\hline Share deaths: neoplasms & & & & & $-0.172^{* *}$ & $-0.18^{* *}$ \\
\hline Share deaths: respiratory & & & & & & \\
\hline Inhabitant registrations (p.c.) & & & & & $222.881 * * *$ & $191.336^{* * *}$ \\
\hline Migration balance & & & & & & \\
\hline Divorces (per 1000 popul.) & & & $1.591 * * *$ & $1.517 * * *$ & & \\
\hline Marriages (per 1000 popul.18-49) & & & & & & \\
\hline Secondary school enrolment (p.c.) & & & $-85.69 * *$ & $-104.616^{* * *}$ & & \\
\hline
\end{tabular}


Table 7b. (cont.)

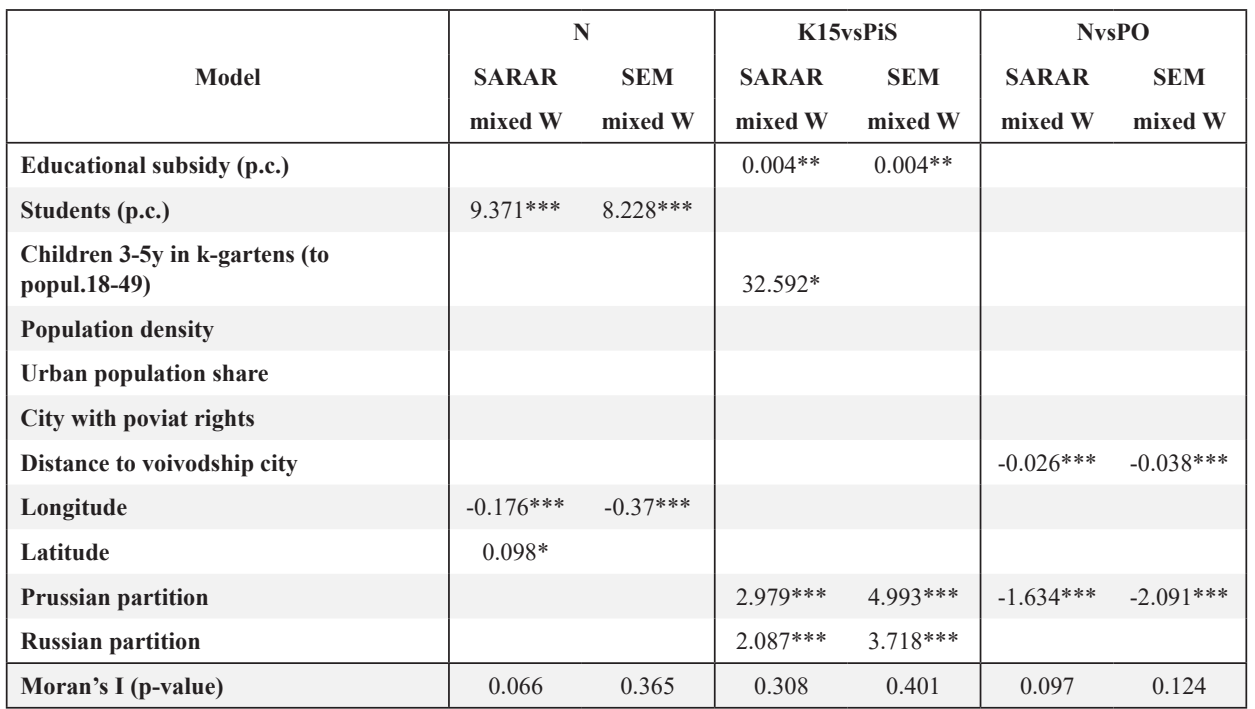

Source: own work.

Table 7c. Mixed-W reduced models for 9 dependent variables $(\mathrm{N}=380)$

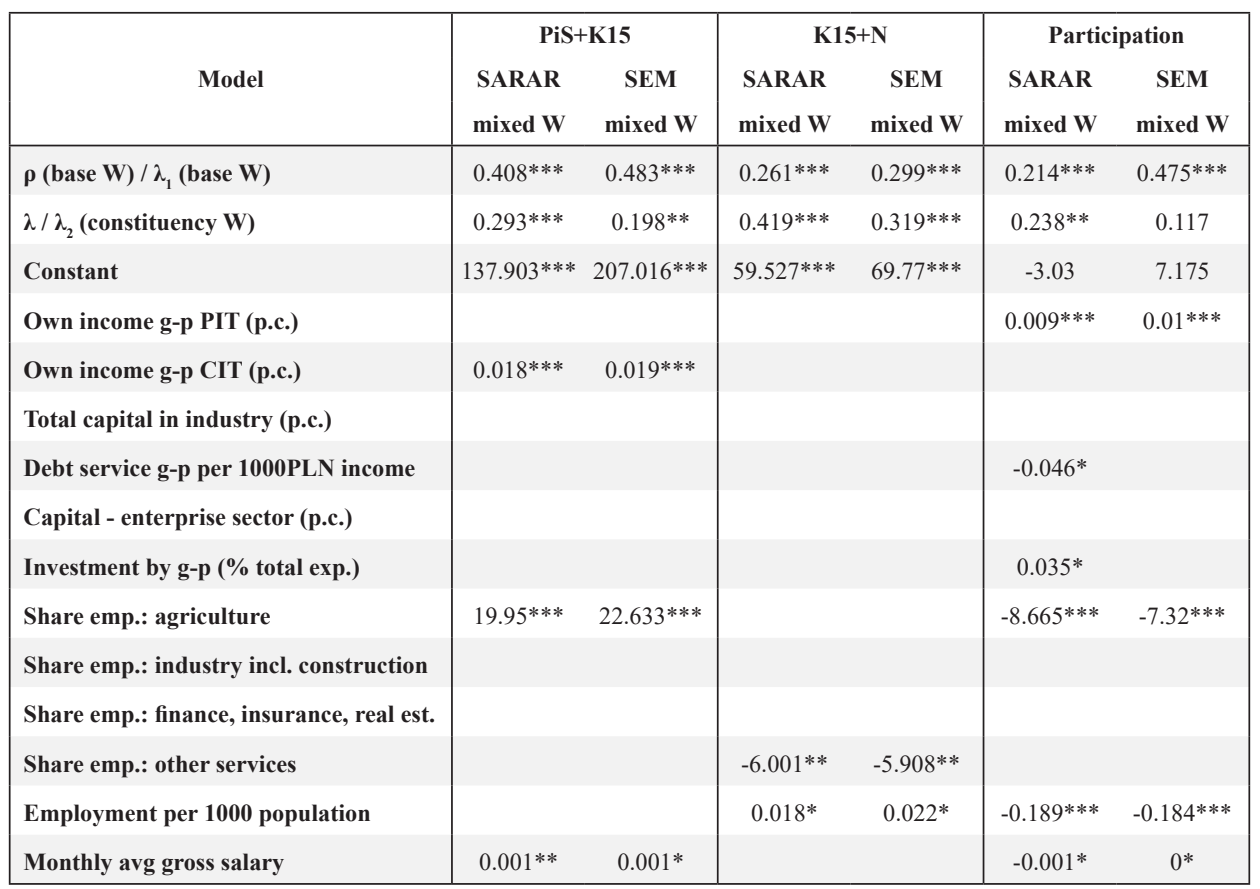


Table 7c. (cont.)

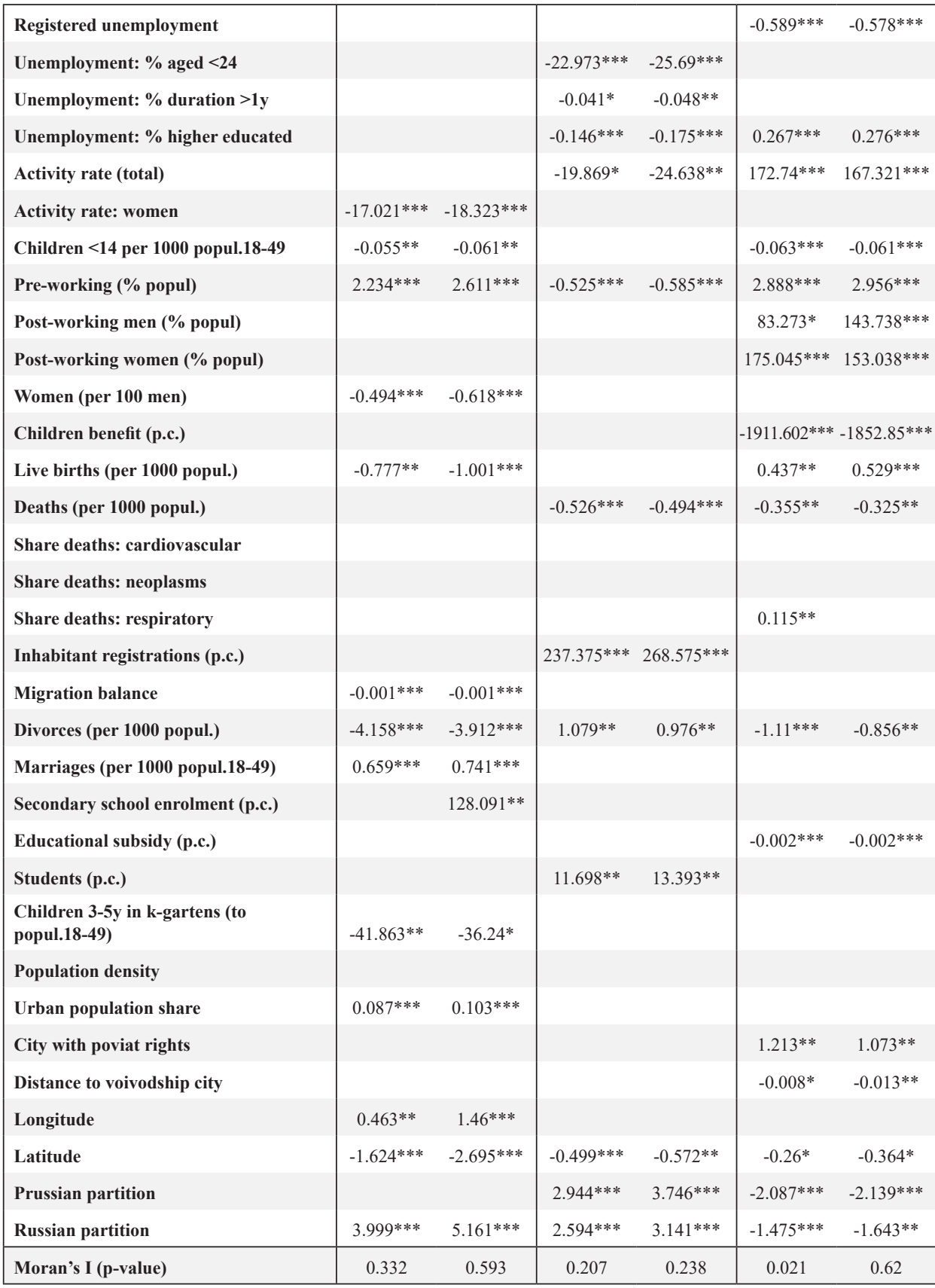

Source: own work. 
Table 8. Principal component models for 9 dependent variables $(\mathrm{N}=380)$

\begin{tabular}{|c|c|c|c|c|c|c|c|c|c|}
\hline \multirow{2}{*}{ Model } & \multicolumn{3}{|c|}{ PiS } & \multicolumn{3}{|c|}{ K15 } & \multicolumn{3}{|c|}{ PO } \\
\hline & OLS & SLM & SEM & OLS & SLM & SEM & OLS & SLM & SEM \\
\hline$\rho$ & \multicolumn{3}{|c|}{$0.807^{* * *}$} & \multicolumn{3}{|c|}{$0.613 * * *$} & \multicolumn{3}{|c|}{$0.766^{* * *}$} \\
\hline$\lambda$ & & & $0.859 * * *$ & & & $0.644 * * *$ & & & $0.872 * * *$ \\
\hline Constant & $39.13 * * *$ & $7.023 * * *$ & $39.486 * * *$ & $9.132 * * *$ & $3.466 * * *$ & $9.063 * * *$ & $22.219 * * *$ & $5.768 * * *$ & $22.644 * * *$ \\
\hline $\begin{array}{l}\text { F01: activity, } \\
\text { employment, cities }\end{array}$ & $1.245 * * *$ & $0.718 * * *$ & $0.716^{* * *}$ & 0.013 & $0.037 *$ & $0.038^{*}$ & $-1.128 * * *$ & $-0.723 * * *$ & $-0.743 * * *$ \\
\hline F02: young & $-0.927 * * *$ & 0.152 & 0.161 & -0.06 & 0.017 & $0.095^{* *}$ & $1.021 * * *$ & 0.044 & 0.034 \\
\hline Moran's I (p-value) & 0 & 0.695 & 0.972 & 0 & 0.703 & 0.787 & 0 & 0.223 & 0.95 \\
\hline \multirow{2}{*}{ Model } & \multicolumn{3}{|c|}{$\mathbf{N}$} & \multicolumn{3}{|c|}{ K15vsPiS } & \multicolumn{3}{|c|}{ NvsPO } \\
\hline & OLS & SLM & & OLS & SLM & & OLS & SLM & SEM \\
\hline$\rho$ & \multicolumn{3}{|c|}{$0.537 * * *$} & \multicolumn{3}{|c|}{$0.74 * * *$} & \multicolumn{3}{|c|}{$0.653 * * *$} \\
\hline$\lambda$ & & & & & & & & & $0.661 * * *$ \\
\hline Constant & $6.005 * * *$ & $2.871 * * *$ & & $19.69 * * *$ & $5.119 * * *$ & & $21.425^{* * *}$ & $7.328 * * *$ & $20.969 * * *$ \\
\hline $\begin{array}{l}\text { F01: activity, } \\
\text { employment, cities }\end{array}$ & $-0.477 * * *$ & $-0.352 * * *$ & & $-0.41 * * *$ & $-0.178 * * *$ & & $-0.319 * * *$ & $-0.194 * * *$ & $-0.243 * * *$ \\
\hline F02: young & $0.331 * * *$ & $0.147 * * *$ & & $0.272 * * *$ & 0.052 & & 0.136 & $0.17 * *$ & $0.382 * * *$ \\
\hline Moran's I (p-value) & 0 & 0.533 & & 0 & 0.913 & & 0 & 0.33 & 0.51 \\
\hline \multirow{2}{*}{ Model } & \multicolumn{3}{|c|}{ PiS+K15 } & \multicolumn{3}{|c|}{$\mathrm{K} 15+\mathrm{N}$} & \multicolumn{3}{|c|}{ Participation } \\
\hline & OLS & SLM & SEM & OLS & SLM & & OLS & SLM & SEM \\
\hline$\rho$ & & $0.764 * * *$ & & & $0.608 * * *$ & & & $0.727 * * *$ & \\
\hline$\lambda$ & & & $0.875^{* * *}$ & & & & & & $0.804 * * *$ \\
\hline Constant & $63.029 * * *$ & $14.001 * * *$ & $62.998 * * *$ & $19.823 * * *$ & $7.785 * * *$ & & $47.168 * * *$ & $13.324 * * *$ & $47.159 * * *$ \\
\hline $\begin{array}{l}\text { F01: activity, } \\
\text { employment, cities }\end{array}$ & $1.889 * * *$ & $1.196 * * *$ & $1.223 * * *$ & $-0.505 * * *$ & $-0.314 * * *$ & & $-0.977 * * *$ & $-0.756 * * *$ & $-0.895 * * *$ \\
\hline F02: young & $-1.645^{* * *}$ & -0.074 & -0.09 & $0.266 * * *$ & $0.117 * *$ & & $0.363 * * *$ & $0.167 * *$ & $0.518 * * *$ \\
\hline Moran's I (p-value) & 0 & 0.195 & 0.982 & 0 & 0.788 & & 0 & 0 & 0.994 \\
\hline
\end{tabular}

Source: own work.

Table 9. Mixed-W principal component models for 9 dependent variables $(\mathrm{N}=380)$

\begin{tabular}{|l|cc|cc|cc|}
\hline \multirow{2}{*}{ Model } & \multicolumn{2}{|c|}{ PiS } & \multicolumn{2}{c|}{ K15 } & \multicolumn{2}{c|}{ PO } \\
& SARAR & SEM & SARAR & SEM & SARAR & SEM \\
mixed W & mixed W & mixed W & mixed W & mixed W & mixed W \\
\hline $\boldsymbol{\rho}$ (base W) $/ \lambda_{1}$ (base W) & $0.743^{* * *}$ & $0.683^{* * *}$ & $0.425^{* * *}$ & $0.443^{* * *}$ & $0.706^{* * *}$ & $0.689^{* * *}$ \\
$\boldsymbol{\lambda} / \boldsymbol{\lambda}_{2}$ (constituency W) & $0.298^{* * *}$ & $0.205^{* * *}$ & $0.418^{* * *}$ & $0.281^{* * *}$ & $0.296^{* * *}$ & $0.21^{* * *}$ \\
Constant & $9.564^{* * *}$ & $39.626^{* * *}$ & $5.201 * * *$ & $9.061 * * *$ & $7.024 * * *$ & $22.181^{* * * *}$ \\
\hline
\end{tabular}


Table 9. (cont.)

\begin{tabular}{|c|c|c|c|c|c|c|}
\hline $\begin{array}{l}\text { F01: activity, employment, } \\
\text { cities }\end{array}$ & $0.767 * * *$ & $0.722 * * *$ & $0.045^{* *}$ & $0.039^{*}$ & $-0.761 * * *$ & $-0.744 * * *$ \\
\hline F02: young & 0.145 & 0.2 & $0.063^{*}$ & $0.108^{* * *}$ & 0.026 & -0.018 \\
\hline Moran's I (p-value) & 0.725 & 0.857 & 0.325 & 0.495 & 0.329 & 0.764 \\
\hline \multirow[b]{2}{*}{ Model } & \multicolumn{2}{|c|}{$\mathbf{N}$} & \multicolumn{2}{|c|}{ K15vsPiS } & \multicolumn{2}{|c|}{ NvsPO } \\
\hline & $\begin{array}{l}\text { SARAR } \\
\text { mixed W }\end{array}$ & $\begin{array}{c}\text { SEM } \\
\text { mixed W }\end{array}$ & $\begin{array}{l}\text { SARAR } \\
\text { mixed W }\end{array}$ & $\begin{array}{c}\text { SEM } \\
\text { mixed W }\end{array}$ & $\begin{array}{l}\text { SARAR } \\
\text { mixed W }\end{array}$ & $\begin{array}{c}\text { SEM } \\
\text { mixed W }\end{array}$ \\
\hline$\rho\left(\right.$ base W) $/ \lambda_{1}($ base W) & $0.517 * * *$ & $0.582 * * *$ & $0.628 * * *$ & $0.569^{* * *}$ & $0.535^{* * *}$ & $0.541 * * *$ \\
\hline$\lambda / \lambda_{2}($ constituency $W)$ & 0.127 & $0.161^{* *}$ & $0.337 * * *$ & $0.252 * * *$ & $0.354 * * *$ & $0.18 * *$ \\
\hline Constant & $2.99 * * *$ & $5.838^{* * *}$ & $7.321 * * *$ & $19.35^{* * *}$ & $9.885^{* * *}$ & $21 * * *$ \\
\hline $\begin{array}{l}\text { F01: activity, employment, } \\
\text { cities }\end{array}$ & $-0.355^{* * *}$ & $-0.348 * * *$ & $-0.185^{* * *}$ & $-0.178 * * *$ & $-0.233 * * *$ & $-0.264 * * *$ \\
\hline F02: young & $0.155^{* * *}$ & $0.186^{* * *}$ & 0.107 & $0.176^{* *}$ & $0.313 * * *$ & $0.425^{* * *}$ \\
\hline Moran's I (p-value) & 0.653 & 0.541 & 0.718 & 0.728 & 0.217 & 0.306 \\
\hline \multirow[b]{2}{*}{ Model } & \multicolumn{2}{|c|}{ PiS+K15 } & \multicolumn{2}{|c|}{$\mathrm{K} 15+\mathrm{N}$} & \multicolumn{2}{|c|}{ Participation } \\
\hline & $\begin{array}{l}\text { SARAR } \\
\text { mixed W }\end{array}$ & $\begin{array}{c}\text { SEM } \\
\text { mixed W }\end{array}$ & $\begin{array}{l}\text { SARAR } \\
\text { mixed W }\end{array}$ & $\begin{array}{c}\text { SEM } \\
\text { mixed W }\end{array}$ & $\begin{array}{l}\text { SARAR } \\
\text { mixed W }\end{array}$ & $\begin{array}{c}\text { SEM } \\
\text { mixed W }\end{array}$ \\
\hline$\rho\left(\right.$ base W) $/ \lambda_{1}$ (base W) & $0.699 * * *$ & $0.696^{* * *}$ & $0.461 * * *$ & $0.436 * * *$ & $0.509^{* * *}$ & $0.634 * * *$ \\
\hline$\lambda / \lambda_{2}$ (constituency $W$ ) & $0.321^{* * *}$ & $0.206^{* * *}$ & $0.402 * * *$ & $0.315^{* * *}$ & $0.616^{* * *}$ & $0.213^{* * *}$ \\
\hline Constant & $18.222 * * *$ & $63.435 * * *$ & $10.708 * * *$ & $19.557 * * *$ & $23.453 * * *$ & $47.075^{* * *}$ \\
\hline $\begin{array}{l}\text { F01: activity, employment, } \\
\text { cities }\end{array}$ & $1.267 * * *$ & $1.234^{* * * *}$ & $-0.329 * * *$ & $-0.326^{* * *}$ & $-0.933 * * *$ & $-0.927 * * *$ \\
\hline F02: young & -0.074 & -0.025 & $0.214 * * *$ & $0.272 * * *$ & $0.466^{* * *}$ & $0.535^{* * *}$ \\
\hline Moran's I (p-value) & 0.387 & 0.846 & 0.623 & 0.461 & 0.081 & 0.923 \\
\hline
\end{tabular}

Source: own work.

\section{THE ROLE OF CONSTITUENCY-SPECIFIC LISTS OF CANDIDATES: DUAL-SOURCE SPATIAL MODELS WITH MIXED-W MATRICES}

On top of the usual spatial dependencies between poviats based on physical proximity, the discontinuity effect emerging from the borders of constituencies can be another aspect of the spatial election process. The presence of electoral districts, and thus the possibility of voting for the same candidates in a cluster of poviats, may influence election results.

Using mixed- $\boldsymbol{W}$ models with two spatial weight matrices, we analysed that possibility. One of those matrices $\left(\boldsymbol{W}_{1}\right)$ represented the geographic proximity criterion (as in all models considered in Section 4). The other indicated two poviats as connected when they both belonged to the same constituency. The quality of candidates may be viewed here as an additional, latent regressor, and hence the latter $\boldsymbol{W}$ matrix 
$\left(\boldsymbol{W}_{2}\right)$ was considered in the spatial error part only. The parameter accompanying this matrix should be estimated as significant if additional unexplained spatial discontinuity around their borders exists (while within-constituency spatial proximity should already be captured by $\boldsymbol{W}_{1}$ ). We applied the estimation method to isolated regions as the capital city Warsaw forms a single-poviat constituency.

While mixed- $\boldsymbol{W}$ SARAR models should in fact be reported as straightforward extensions of the baseline models for all dependent variables except the turnout, we reported both mixed- $\boldsymbol{W}$ SARAR and mixed-W SEM estimates in all cases for the purpose of robustness check:

$$
\begin{array}{ll}
\text { Mixed-W SARAR: } & y_{i}=\rho W_{1} y_{i}+x_{i} \beta+\left(I-\lambda W_{2}\right) \varepsilon_{i} ; \\
\text { Mixed-W SEM: } & y_{i}=x_{i} \beta+\left(I-\lambda_{1} W_{1}\right)\left(I-\lambda_{2} W_{2}\right) \varepsilon_{i} .
\end{array}
$$

Estimates from mixed- $\boldsymbol{W}$ SARAR and SEM models were presented in Tables 7 and 9. They generally confirmed our hypothesis $\mathbf{H 2}$ about the existence of the unobservable effects related to the candidates' attractiveness in individual constituencies ( $\lambda$ and $\lambda_{2}$ coefficients proved statistically significant in almost all cases, as confirmed by the likelihood ratio tests). The only cases in which they appeared as insignificant were the fractions of votes for the newcomers - K15 and N-as represented by relatively unknown, and hence less charismatic leaders of the lists than in the case of PO and PiS. However, it is noteworthy that even K15 and N exhibited this effect when their results were evaluated in relation to their segment competitors, i.e. PiS and $\mathrm{PO}$ respectively.

Both in the models with principal components and reduced models with original variables on the right-hand side of the equation, only minor changes in variable significance arose. If anything, individual explanatory variables tend to lose (rather than gain) statistical significance.

In the analysed cases of mixed- $\boldsymbol{W}$ SARAR models, the sum of $\rho$ and $\lambda$ is higher than the respective values of $\rho$ considered in Section 4. The explicit inclusion of another source of spatial dependence, i.e. candidates' attractiveness in individual constituencies, improves the goodness of fit - in most cases, the log-likelihood for mixed- $\boldsymbol{W}$ models is higher than for SAR (spatial autoregressive models; see Table 10). K15 (in the run-up against PiS) is the only exception and it may be due to the presence of only one distinctive leader in one district (Paweł Kukiz himself).

This conclusion is robust with respect to the variant of $\boldsymbol{W}_{1}$ under consideration. In the first alternative version (poviats connected when centroids located up to 60 $\mathrm{km}$ from each other), the constituency-related parameter $\lambda$ in (3) (or is $\lambda_{2}$ in (4)) was significant in all cases (even K15 and N). The same is true for the second alternative version (spatial weight matrix based on inverted distance), although it must be noted that for most of the dependent variables in question, this version of $\boldsymbol{W}_{1}$ leaves significant spatial autocorrelation in mixed- $\boldsymbol{W}$ model residuals. ${ }^{13}$

${ }^{13}$ Complete results available upon request. 
The fact of accounting for constituency-specific lists of candidates as a latent determinant of electoral behaviours can be an important source of reducing spurious significances of other spatially correlated variables. In the political economy literature, this mechanism is technically similar in nature to including vertical interactions (variables describing upper-tier authority expenditures) in models of interaction between lower-tier authority expenditures (cf. Reveli, 2003). As demonstrated by Reveli for English local government expenditures, when vertical fiscal externalities among upper-tier (County) authority and lower-tier (District) authority expenditures were taken into account, the estimated magnitude of fiscal interactions between districts was substantially reduced. Omitting the vertical fiscal interactions can give the false impression of spatial interaction at the horizontal level and, by the same token, the fact of omitting the effect of constituencies can give a false impression of a strong spatial autoregression between individual poviats (lower tier than constituencies).

Table 10. Comparison of log-likelihood between SLM and respective mixed-W models

\begin{tabular}{|l|cc|cc|}
\hline & $\begin{array}{c}\text { SLM } \\
\text { (reduced) }\end{array}$ & $\begin{array}{c}\text { SARAR } \\
\text { (reduced, } \\
\text { mixed-W) }\end{array}$ & $\begin{array}{c}\text { SLM } \\
\text { (PCA- } \\
\text { reduced) }\end{array}$ & $\begin{array}{c}\text { SARAR } \\
\text { (PCA-reduced, } \\
\text { mixed-W) }\end{array}$ \\
\hline PiS [\% all] & -1068.5 & $\mathbf{- 1 0 6 3 . 7}$ & -1157.2 & $\mathbf{- 1 1 5 3 . 9}$ \\
K15 [\% all] & -652.3 & $\mathbf{- 6 5 0 . 2}$ & -699.6 & $\mathbf{- 6 9 1 . 4}$ \\
PO [\% all] & -923.8 & $\mathbf{- 9 1 8 . 3}$ & -1021.3 & $\mathbf{- 1 0 1 8 . 0}$ \\
N [\% all] & -592.8 & $\mathbf{- 5 9 2 . 4}$ & -641.7 & $\mathbf{- 6 4 0 . 9}$ \\
K15 [\% K15 + PiS] & $\mathbf{- 9 2 1 . 2}$ & -924.6 & -987.5 & $\mathbf{- 9 8 3 . 9}$ \\
N [\% N + PO] & -1013.7 & $\mathbf{- 1 0 1 0 . 4}$ & -1059.7 & $\mathbf{- 1 0 5 3 . 7}$ \\
PiS + K15 [\% 4 parties] & -1073.2 & $\mathbf{- 1 0 6 7 . 3}$ & -1178.9 & $\mathbf{- 1 1 7 4 . 7}$ \\
N + K15 [\% 4 parties] & -847.2 & $\mathbf{- 8 3 6 . 3}$ & -895.3 & $\mathbf{- 8 8 7 . 1}$ \\
Participation [\%] & -787.4 & $\mathbf{- 7 8 1 . 1}$ & -992.4 & $\mathbf{- 9 5 8 . 8}$ \\
\hline
\end{tabular}

Source: own work.

\section{CONCLUSIONS}

We conducted a spatial econometric investigation of the 2015 Polish parliamentary election results, examining the determinants of choosing the incumbent (PO) versus the opposition (PiS), right-wing $(\mathrm{PiS}+\mathrm{K} 15)$ versus liberal $(\mathrm{PO}+\mathrm{N})$, as well as well established (PO+PiS) versus newly created parties $(\mathrm{K} 15+\mathrm{N})$. Our analysis was located in the strand of spatial political economy literature and based 
on regional data on the poviat level (380 units at the NUTS-4 level in the European Union nomenclature). We considered a broad set of socio-economic explanatory variables, selected by the General-to-specific principle and additionally supported by Bayesian model averaging, as well as used as input for the construction of 11 principal components.

Our results generally confirmed that traditional factors, such as a region's economic activity, demographic profile and north-west versus southeast orientation, continue to play a dominant role in the distribution of electoral support between the liberal and right-wing groups. However, the full picture appeared more nuanced: big cities tended to give more support towards right-wing parties (after controlling economic activity and demography), and the variables related directly to key promises during the electoral campaign (e.g. targeted at parents of young children and people nearing the retirement age) did not affect the results, at least not from the spatial perspective. At the same time, the spatial patterns in newcomers' results ( $\mathrm{N}$ and, especially, K15) suggested that the geographical dimension of anti-establishment sentiments in Poland were more difficult to capture.

The data offered strong support for using spatial models, predominantly the spatial autoregression. The robust Lagrange multiplier tests prefer this specification over the spatial error model in most cases, which suggests that the spatial interactions of the dependent variable are a more likely spatial process than the spatial process of error autocorrelation that might have been due to an omission of important explanatory variables. The switch from non-spatial perspective (OLS estimation) to spatial models affected a number of conclusions about individual variable significance. Moran's I tests of the residuals confirmed that single source models (with neighbourhood-based $\boldsymbol{W}$ matrix) were sufficient to remove the spatial autocorrelation from the residuals.

Using mixed- $\boldsymbol{W}$ spatial models with an additional spatial weight matrix representing the adherence to the same constituencies, we also demonstrated that the latent effect of sharing the same candidate list offerede a significant contribution to election results. This conclusion was robust over political parties and model specifications (both SEM, turned into mixed- $\boldsymbol{W}$ SEM, and SAR, turned into mixed- $\boldsymbol{W}$ SARAR).

Future research could confront the 2015 election results with analogous upcoming results in 2019, as long as the system of constituencies persists, the set of parties running up for the victory remains stable and the socio-economic context of the campaign remains unchanged, at least to a decent extent. Another issue worth investigation is the combining of the regional dataset with micro-data (if available) into a spatial multilevel model. The impact of constituencies could be re-tested, backwards or forwards in time, regardless of the abovementioned circumstances, unless single-candidate elections are introduced. It could also be interesting to investigate this effect in an international panel, combining countries with similar, proportional, constituency-based electoral system. 


\section{REFERENCES}

ALGAN, Y., GURIEV, S., PAPAIOANNOU, E. and PASSARI, E. (2017), 'The European Trust Crisis and the Rise of Populism', Centre for Economic Policy Research Discussion Papers, DP12444, November 2017.

ANSOLABEHERE, S. and KONISKY, D.M. (2006), The introduction of voter registration and its effect on turnout, Political Analysis, 14, pp. 83-100.

BARISIONE, M. (2009), So, what difference do leaders make? Candidates' images and the 'conditionality' of leader effects on voting, Journal of Elections, Public Opinion and Parties, 4, pp. 473-500.

BIEGAŃSKA, J. and SZYMAŃSKA, D. (2013), 'The scale and the dynamics of permanent migration in rural and peri-urban areas in Poland - some problems', [in:] SZYMAŃSKA, D. and CHODKOWSKA-MISZCZUK, J. (eds.), Bulletin of Geography. Socio-economic Series, 21, pp. 21-30. Torun: Nicolaus Copernicus University Press.

BITTNER, A. (2018), Leaders always mattered: The persistence of personality in Canadian elections, Electoral Studies, 54, pp. 297-302.

CAMPOS, J., ERICSSON, N.R. and HENDRY D.F. (eds.), (2003), Readings on General-to-Specific Modeling. Cheltenham: Edward Elgar.

CANCELA, J. and GEYS, B. (2016), 'Explaining voter turnout: A meta-analysis of national and subnational elections', European Studies, 42, pp. 264-275.

CHEN, J. and RODDEN, J. (2013), 'Unintentional Gerrymandering: Political Geography and Electoral Bias in Legislatures', Quarterly Journal of Political Science, 8, pp. 239-269.

CHO, W., GIMPEL, J. and HUI, I. (2012), 'Voter Migration and the Geographic Sorting of the American Electorate', Annals of the Association of American Geographers, 103.

CORNELIS, I., VAN HIEL, A., ROETS, A. and KOSSOWSKA, M. (2009), 'Age differences in conservatism: Evidence on the mediating effects of personality and cognitive style', Journal of Personality, 77, pp. 51-88.

DARMOFAL, D. (2006), 'Spatial Econometrics and Political Science', Annual Meeting of the Southern Political Science Association, Atlanta, GA, January, pp. 5-7.

DETTREY, B.J., SCHWINDT-BAYER, L.A. (2009), Voter Turnout in Presidential Democracies, Comparative Political Studies, 42 (10), pp. 1317-1338.

EGGERS, A.C. (2015), Proportionality and Turnout: Evidence From French Municipalities, Comparative Political Studies, 48 (2), pp. 135-167.

ENDERSBY, J.W., KRIECKHAUS, J.T. (2008). Turnout around the globe: the influence of electoral institutions on national voter participation, 1972-2000, Electoral Studies, 27, pp. 601-610.

FAUVELLE-AYMAR, C. and FRANÇOIS, A. (2006), The impact of closeness on turnout: an empirical relation based on a study of a two-round ballot, Public Choice, 127, pp. 469-491.

FOWLER, A. (2013), Electoral and policy consequences of voter turnout: evidence from compulsory voting in Australia, Quarterly Journal of Political Science, 8, pp. 159-182.

GARZIA, D. (2011), The personalization of politics in Western democracies: Causes and consequences on leader-follower relationships, The Leadership Quarterly, 22 (4), pp. 697-709.

GARZIA, D. (2012), Party and Leader Effects in Parliamentary Elections: Towards a Reassessment, Politics, 32 (3).

VAN GENT, W.P.C., JANSEN, E.F. and SMITS J.H.F. (2013), 'Right-wing Radical Populism in City and Suburbs: An Electoral Geography of the Partij Voor de Vrijheid in the Netherlands', Urban Studies, pp. 1-20, DOI: 10.1177/0042098013505889.

GEYS, B. (2006), 'Explaining voter turnout: A review of aggregate-level research', Electoral Studies, 25, pp. 637-663. 
HOGAN, R.E. (2013), Campaign spending and voter participation in state legislative elections, Social Science Quarterly, 94, pp. 840-864.

HOLBROOK, T.M. and WEINSCHENK, A.C. (2014), Campaigns, Mobilization, and Turnout in Mayoral Elections, Political Research Quarterly, 67 (1), pp. 42-55.

JABŁONOWSKI, J. and MÜLLER, C. (2013), '3 sides of 1 coin - Long-term Fiscal Stability, Adequacy and Intergenerational Redistribution of the reformed Old-age Pension System in Poland', National Bank Of Poland Working Paper, 145.

KOOP, G. (2003), Bayesian Econometrics, John Wiley \& Sons, Chapter 11: Bayesian Model Averaging.

KOWALSKI, M., (2003), 'Polaryzacja zachowań wyborczych w Polsce jako rezultat cywilizacyjnego rozdarcia kraju’, Przestrzeń wyborcza Polski, Polskie Towarzystwo Geograficzne Oddział Akademicki, Warsaw.

KRZEMIŃSKI, P. (2009), 'Zachowania wyborcze w wyborach parlamentarnych i prezydenckich w Polsce w latach 2005-2007 - wzory przestrzennych zróżnicowań', Przegląd Geograficzny, $81(2)$.

MANSLEY, E. and DEMSAR, U. (2015), 'Space matters: Geographic variability of electoral turnout determinants in the 2012 London mayoral election', Electoral Studies, 40, pp. 322-334.

Ministry of Regional Development in Poland, Poland National Strategic Reference Framework 2007-2013, URL https://www.funduszeeuropejskie.2007-2013.gov.pl/WstepDoFunduszyEuropejskich/Documents/NSRO_an_20_07.pdf (accessed on: 31.07.2018).

MORTON, A.D. (2017), 'Spatial Political Economy', Journal of Australian Political Economy, 77, pp. 21-38.

MUGHAN, A. (2015), Parties, conditionality and leader effects in parliamentary elections, Party Politics, 21 (1), pp. 28-39.

NIKOLENYI, C. (2010), 'Concurrent Elections and Voter Turnout: The Effect of the De-Linking of State Elections on Electoral Participation in India's Parliamentary Polls, 1971-2004', Political Studies, 58 (1), pp. 214-233.

PESZYŃSKI, W. (2016), 'Prezydencjalizacja zachowań wyborczych w elekcji parlamentarnej w 2015 roku', Political Preferences, 12, pp. 37-54.

RAHAT, G. and SHEAFER, T. (2007), 'The personalization(s) of politics: Israel 1949-2003', Political Communication, 24, pp. 65-80.

REVELLI, F. (2003), 'Reaction or interaction? Spatial process identification in multi-tiered government structures', Journal of Urban Economics, 53 (1), pp. 29-53.

SAIB, M. (2017), 'Spatial Autocorrelation in Voting Turnout', Journal of Biometrics \& Biostatistics, 8 .

SEABROOK, N. (2009), 'The Obama Effect: Patterns of Geographic Clustering in the 2004 and 2008 Presidential Elections', The Forum, 7 (2), Article 6.

TRUETT, K.R. (1993), 'Age differences in conservatism', Personality and Individual Differences, 14, pp. 405-411.

TURSKA-KAWA, A. (2016), 'Preferowane wartości podstawowe a zachowania wyborcze w elekcji parlamentarnej 2015 roku', Political Preferences, 13, pp. 105-118.

WCISEŁ, W. (2016), 'Migratory crisis in the eyes of the party leaders during the parliamentary campaign in Poland in 2015', Political Preferences, 13, pp. 21-34.

WILSON, G.D. (1973), The psychology of conservatism, Oxford, England: Academic Press.

ZARYCKI, T. (1997), 'Nowa przestrzeń społeczno-polityczna Polski', Studia Regionalne i Lokalne, 23 (56), Warsaw: Europejski Instytut Rozwoju Regionalnego i Lokalnego, UW.

ŻERKOWSKA-BALAS, M., LYUBASHENKO, I. and KWIATKOWSKA, A. (2016), 'Determinanty Preferencji Wyborczych: Polska w latach 1997-2015', Studia Socjologiczne, 4 (223), pp. 69-92. 